\title{
FIRST OBSERVATIONS OF UV-INDUCED FLUORESCENCE IN HELIAMPHORA (SARRACENIACEAE) AND OTHER TEPUI FLORA
}

MICHAL R. GOLOS • School of Biological Sciences • University of Bristol $\bullet 24$ Tyndall Avenue $・$ Bristol
BS8 1TQ $•$ UK $• \underline{\text { michal.golos @ bristol.ac.uk }}$

Keywords: fluorescence, Heliamphora, morphology, phytochemistry, pitcher infauna, prey attraction, tepuis, visual ecology

Abstract: Seven species of the carnivorous plant genus Heliamphora were studied in the wild across four tepuis of the Venezuelan Guyana. All were found to exhibit UV-induced blue fluorescence in their young and developing pitchers, the fluorescence being largely confined to the downward-pointing trichomes of the pitcher interior, with a small contribution from the nectaries. Subsequent work on cultivated plants confirmed the universality of this trait across all known members of the genus. Fluorescence microscopy localised the blue emissions to the surface of the trichomes and unequivocally showed that it represents true fluorescence. The phenomenon was found to be highly transient, generally being seen only in recently opened pitchers. Whether it has a biological function or is an incidental property remains to be determined. Possible roles in the attraction of prey and pitcher inquilines are discussed.

\section{Introduction}

Heliamphora is a Neotropical genus of pitcher plants found primarily in Venezuela but whose range also extends into neighbouring parts of Brazil and Guyana. The vast majority of the 23 currently recognised species are restricted to the summit plateaus and upper slopes of the distinctive table-mountains (tepuis) of the region, which are renowned for hosting a highly diverse and specialised plant community (McPherson et al. 2011).

The above-ground vegetative parts of Heliamphora consist solely of the tubular leaves (pitchers), which often bear an apical appendage (the lid or 'nectar spoon') wherein the nectaries are concentrated and shielded from rain. In most species, the upper portion of the pitcher interior has a uniform covering of downward-pointing non-glandular trichomes (retentive hairs). These range in size from microscopic to several millimetres long, depending on the species. The trichomes are unicellular, their bases anchored in raised portions of epidermis and underlying parenchyma (Lloyd 1942; Płachno et al. 2007; Poppinga et al. 2010). Owing to their striate micro-ornamentation these hairs have anisotropic and hydrophilic properties and, when wetted, capture insects by means of 'aquaplaning' (Bauer et al. 2013). A minority of speciesnamely $H$. ceracea, $H$. chimantensis, $H$. glabra, $H$. macdonaldae, $H$. sarracenioides, and $H$. folliculata (variably) - lack retentive hairs across the main trapping surfaces of mature pitchers (McPherson et al. 2011). ${ }^{1}$ Of these, H. ceracea, H. glabra and H. macdonaldae instead have a conspicuous waxy coating reminiscent of the 'waxy zone' found in Old World pitcher plants of the genus Nepenthes and Neotropical carnivorous bromeliads of the genera Brocchinia and Catopsis (see Gaume et al. 2004; McPherson 2006).

Fluorescence, a form of photoluminescence, involves the absorption of electromagnetic radiation at shorter wavelengths and almost immediate emission at longer wavelengths (with rare, likely nonbiologically relevant exceptions). Once the source of excitatory radiation is extinguished, so too is the fluorescent emission, on a nanosecond timescale. In this it differs from phosphorescence, where the emitted radiation persists much longer (milliseconds to hours) and which has a different underlying mechanism (see García-Plazaola et al. 2015). Fluorescence in plants has long been the subject of scientific inquiry (Lloyd

\footnotetext{
${ }^{1}$ Though mature pitchers of these species are glabrous throughout much of their interior, they nonetheless possess two features apparently common to all species: a narrow band of hairs around the waterline and a zone of submerged hairs near the very bottom of the pitcher tube, the function of which is unknown (McPherson et al. 2011). Often, a conspicuous ring of trichomes also lines the margin of the pitcher mouth, as clearly seen in e.g. Heliamphora macdonaldae.
} 
1924) and the best-known example is undoubtedly that of chlorophyll $a$, which emits in the red to far-red, though blue-green plant fluorescence is also common (Buschmann et al. 2000). No studies on fluorescence in Heliamphora have previously been published, but Kurup et al. (2013) claimed to show that three other carnivorous plant genera-Dionaea, Nepenthes, and the closely related Sarracenia-employ UV-induced blue fluorescence as a visual lure to attract prey. The results were widely reported (Warwicker 2013; Bloudoff-Indelicato 2013; Stromberg 2013), but concerns were soon raised about the study's methodology and conclusions (Hartmeyer et al. 2013; Jansen 2017). Clearly, more work is needed to elucidate the basis and functional importance (if any) of this phenomenon.

Methods

\section{Field observations}

Field studies were carried out between January and February 2017 on eight taxa (seven species and one non-autonymic variety) of Heliamphora across the summit plateaus of four tepuis: $H$. chimantensis on Apacará-tepui (part of the northern Chimantá Massif complex); H. huberi, H. pulchella and H. uncinata on Amurí-tepui (part of the southern Chimantá Massif complex); H. minor var. minor and H. minor var. pilosa on Auyán-tepui; and $H$. purpurascens and $H$. sarracenioides on Ptari-tepui. Additionally, Catopsis berteroniana was imaged on the lower slopes of Auyán-tepui, and Xyris sp. and an undetermined Eriocaulaceae were photographed on the summit plateau of Ptari-tepui. Heliamphora huberi and $H$. uncinata could only be studied in daylight owing to their inaccessibility; they therefore had to be artificially shaded prior to being photographed. The UV-induced fluorescence of the five remaining Heliamphora species (as well as the other tepui flora) was imaged at night. In all cases a tripod-mounted Nikon D810 was used, equipped with a Nikon AF-S Nikkor 24-120 mm f/4G ED VR lens and Hoya HMC UV(C) filter. The source of the excitatory UV light was a Nitecore CU6 Chameleon hand torch (Sysmax Innovations Co., Guangzhou, China) possessing a $3000 \mathrm{~mW}$ UV LED emitting a relatively narrow spectrum peaking at $365 \mathrm{~nm}$. Though better in this regard than many of its competitors, this flashlight nonetheless emits an appreciable amount of visible light in the blue end of the spectrum and so care was taken to distinguish true blue fluorescence caused by excitatory UV radiation from mere reflections of bluish light (cf. Bazile 2013; Hartmeyer et al. 2013). The white LED (CREE XP-G2) of the Nitecore CU6 torch was used for the whitelight photos taken in the field at night. White-light photos of cultivated plants were taken under "cool white" $(4000 \mathrm{~K})$ fluorescent tubes. With the sole exception of the scorpion photo (which was heavily overexposed), none of the images presented in this paper have been postprocessed with respect to colorimetric values, having undergone only default in-camera RAW-to-JPEG conversion. Nevertheless, between-image differences in fluorescence intensity should not be taken as biologically relevant, as they may simply reflect varying exposure settings.

Readers wishing to run their own experiments are advised that the use of a high-power UV torch brings with it important safety considerations, owing to both the intensity of the UV radiation and its imperceptibility, with even reflections posing a potential risk. Misuse can easily lead to irreparable eye damage! At the very least, appropriate eye (and preferably also skin) protection should be worn at all times. For more information on UV-induced visible fluorescence photography, see Holovachov (2015a), Brecko et al. (2016), Ingles-Le Nobel (2018), and Blum (2019).

\section{Observations of cultivated plants}

All remaining species of Heliamphora that could not be studied in the wild were observed as cultivated specimens in the author's live collection. To confirm fluorescence, plants were viewed under the same Nitecore CU6 UV torch as before. Photographs were captured with a tripod-mounted camera (either Nikon D810 or Nikon D7100). The UV torch was either mounted on a plamp (plant clamp) or, when a larger area required illumination, handheld and moved across the subject to 'paint' it with UV radiation over the course of a long exposure. 


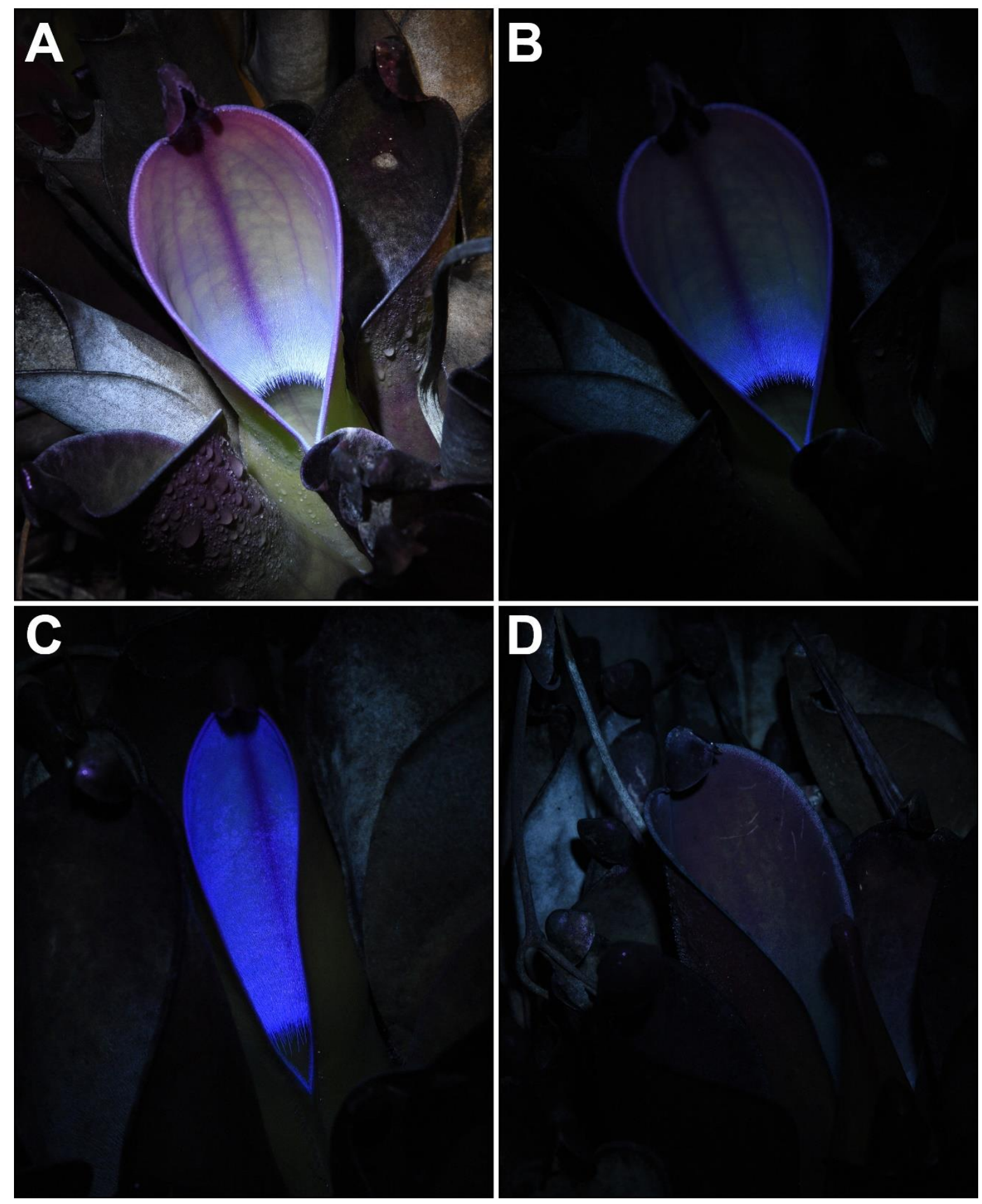

Figure 1: Heliamphora chimantensis on Apacará-tepui: (A-B) a freshly opened pitcher under white and UV illumination; here the majority of the inner pitcher surface lacks conspicuous blue fluorescence, the trichomes being confined to the area just above the waterline and to a narrow band lining the pitcher rim; $(C)$ a pitcher in the process of opening; here the entire inner surface is lined with hairs and shows uniformly strong blue fluorescence; (D) an older pitcher from the same patch, showing no obvious UV-induced fluorescence (the pitcher is illuminated only by the small amount of visible light emitted by the UV torch, which necessitated a longer exposure). 


\section{Fluorescence microscopy}

Small pieces of tissue were cut from a freshly opened Heliamphora pulchella (Amurí-tepui) pitcher from the author's collection. The tissue was viewed under a dissecting microscope and two types of slides prepared: isolated hairs and hairs with surrounding tissue. Individual trichomes were plucked with tweezers, while thin slices of tissue were taken with a scalpel blade. In each case the sample was placed on a glass slide, covered in Citifluor antifadent mountant solution, and coverslipped. Nail polish was used to secure the coverslips in place. The slides were then viewed under a Leica DM4 B fluorescence microscope. The samples were imaged under bright-field illumination as well as four different fluorescence filter cubes: DAPI (excitation range, EX: 325-375 nm; dichromatic mirror, DC: $400 \mathrm{~nm}$; emission range, EM: 435-485 nm), GFP (EX: 450-490 nm; DC: $495 \mathrm{~nm}$; EM: 500-550 nm), TXR (EX: 540-580 nm; DC: $585 \mathrm{~nm}$; EM: 592-668 nm), and CR (custom filter cube for imaging Congo red fluorescence: EX: $497 \mathrm{~nm}$; EM: $614 \mathrm{~nm}$ ).

\section{Results}

\section{All known Heliamphora exhibit UV-induced blue fluorescence in their pitcher interiors}

Field observations confirmed the presence of UV-induced blue fluorescence in seven species and one non-autonymic variety of Heliamphora (Figs. 1-7). Observations on cultivated plants of all remaining Heliamphora species showed that some level of blue fluorescence is exhibited by all members of the genus, though it is highly variable in its intensity, localisation, and persistence (Figs. 8-12). Significant intraspecific variation was also observed: the fluorescence of $H$. minor var. pilosa, for example, is much more conspicuous than that of H. minor var. minor (Fig. 3).
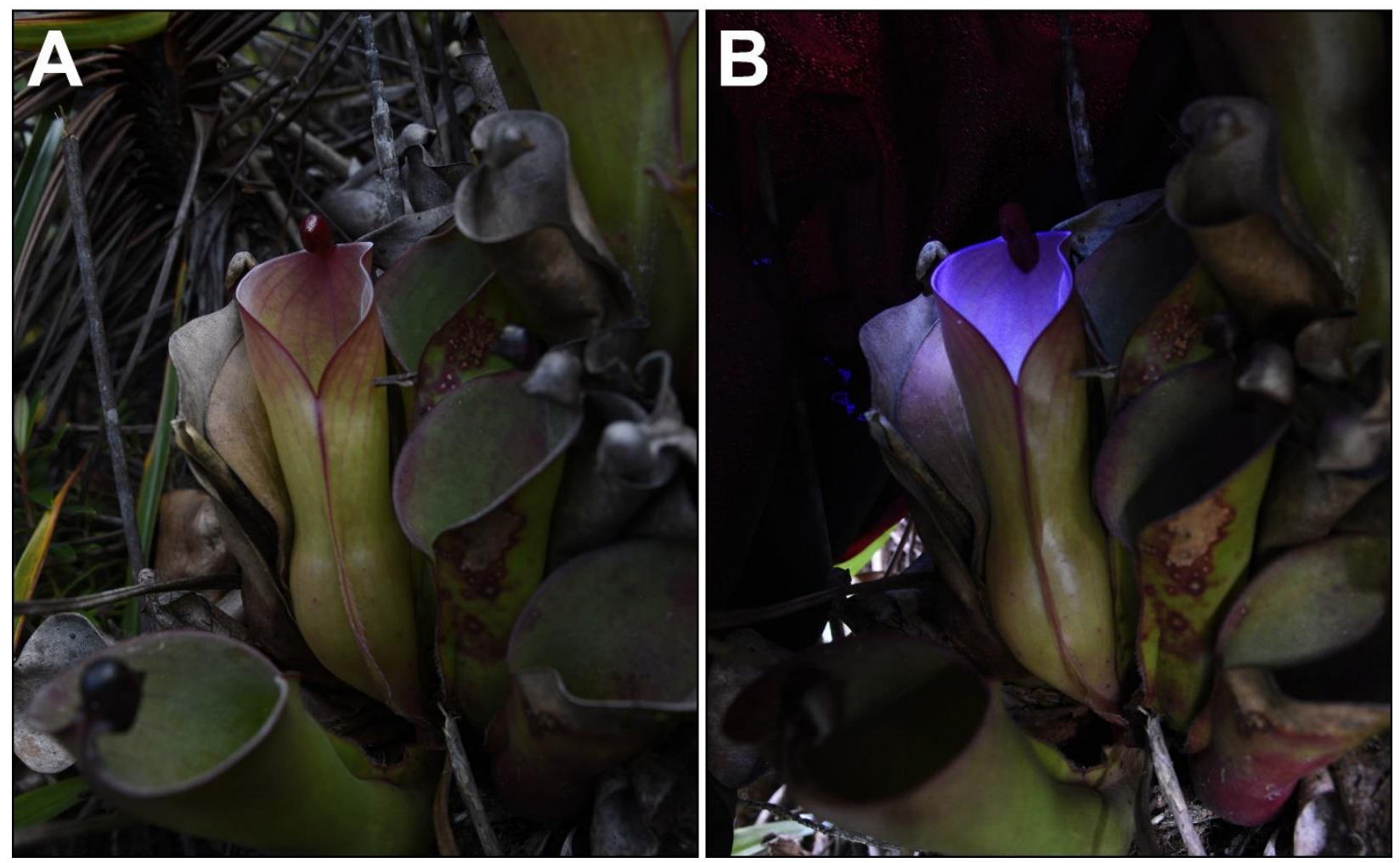

Figure 2: Heliamphora huberi on Amurí-tepui under ambient light (A) and a combination of artificial shade and UV illumination (B), showing striking fluorescence in the interior of the newly opened pitcher. Though appearing violet, this colouration is likely skewed by red light filtering through the overlying sleeping bag (compare Fig. 11B). 


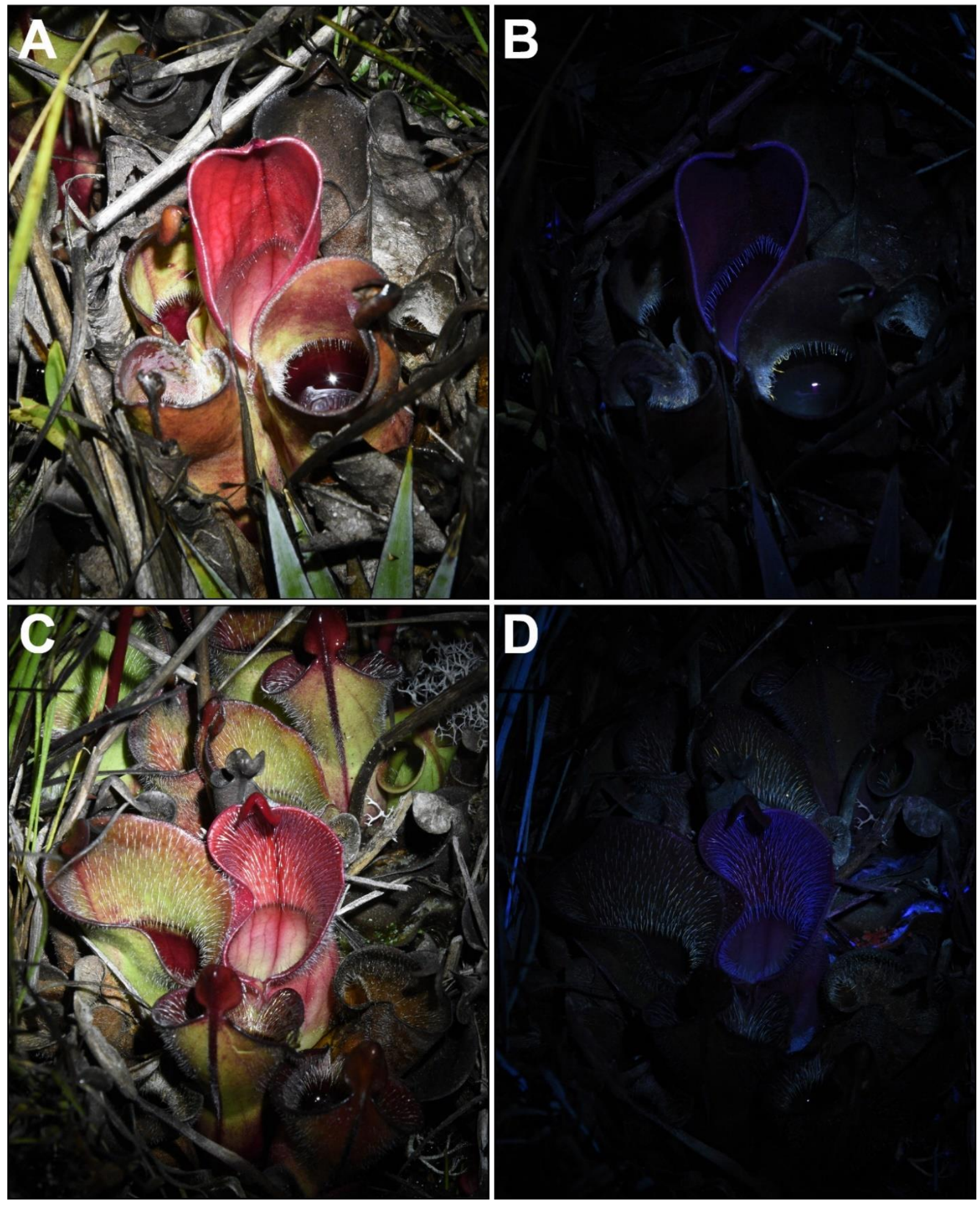

Figure 3: Heliamphora minor on Auyán-tepui: (A-B) H. minor var. minor under white and UV illumination, the latter showing a fluorescing ring of trichomes just above the waterline and another around the pitcher rim; (C-D) H. minor var. pilosa, showing widespread trichome fluorescence; note the blue fluorescence of the nectaries on the underside of the lid and yellow fluorescence of individual trichomes (presumably due to organic surface contaminants). 


\section{Retentive hairs are the main source of fluorescence, followed by nectaries}

Retentive hairs of all studied Heliamphora species were found to exhibit blue fluorescence. Under fluorescence microscopy, the trichomes were the only sampled parts of the trapping surface to show significant blue fluorescence under UV, with the surrounding epidermal tissue emitting no perceptible fluorescence (Fig. 13). This situation was largely reversed when the excitatory light was changed to blue and the emissions filtered to green, with the epidermal tissue showing strong green fluorescence in contrast to the weakly visible trichomes (Fig. 14). Similarly, no trichome fluorescence was observed at the longer excitatory wavelengths. These microscopy studies unequivocally showed that the blue emissions represent true UV-induced fluorescence and not merely reflected blue light. Interestingly, trichomes that exhibit strong blue fluorescence also look appreciably different under natural light, having a bright white lustre, as compared to the markedly duller appearance of non-fluorescing trichomes (Fig. 2A).

Wild Heliamphora sarracenioides pitchers were found to fluoresce internally despite lacking retentive hairs (Fig. 7). Subsequent observations revealed that Heliamphora pitcher nectaries also give off blue fluorescence (Fig. 3D, 10B), as does the nectar itself (Fig. 12). In internally hirsute species, the retentive hairs were identified as the primary source of blue fluorescence, with a small contribution from the nectaries. Unsurprisingly, internally glabrous species exhibit far lower overall fluorescence intensities.

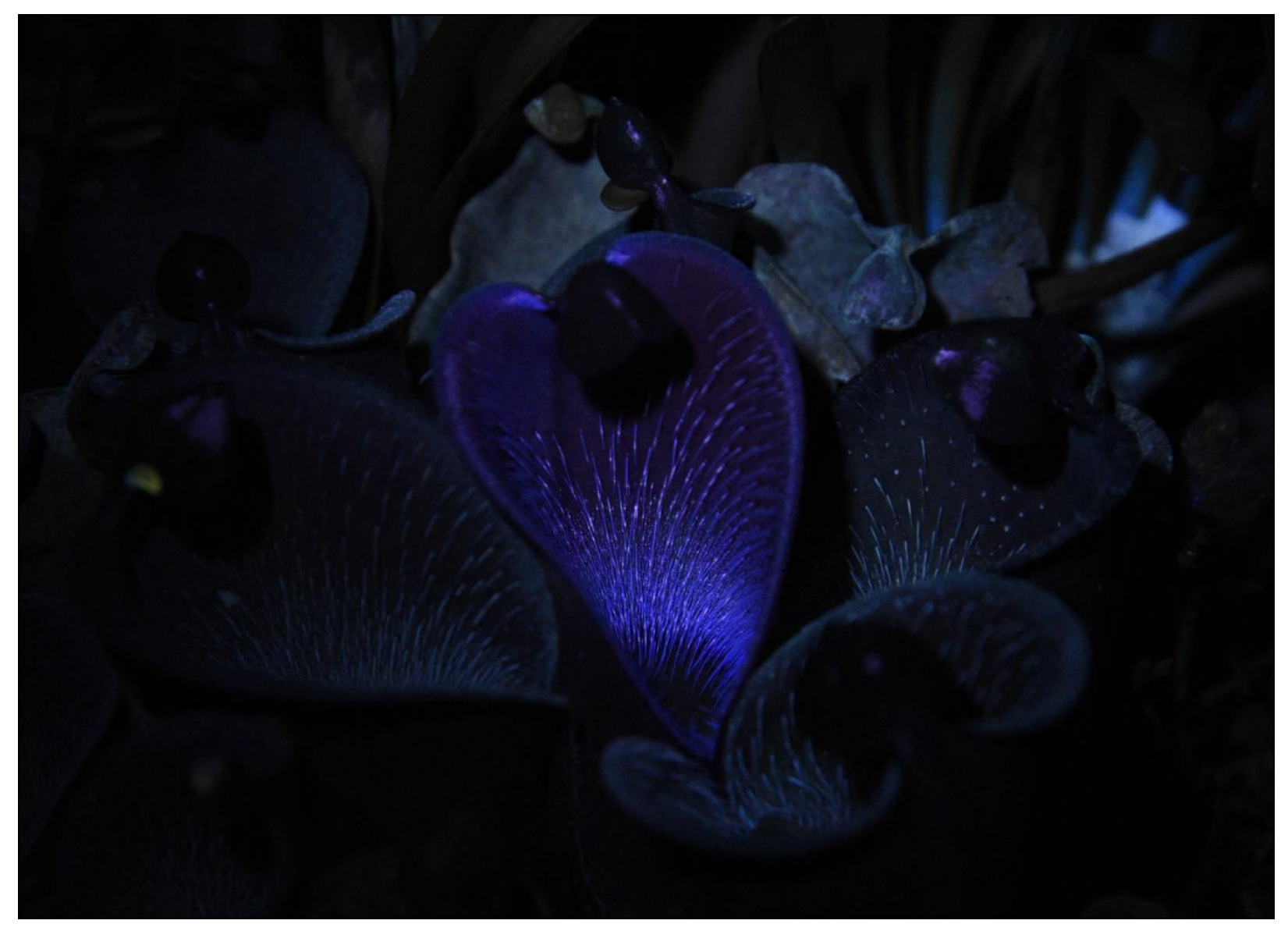

Figure 4: Heliamphora pulchella on Amurí-tepui. The strongest blue fluorescence corresponds to the high density of trichomes near the fluid level. 


\section{Trichome fluorescence is transient and strongest in young pitchers}

Developing and freshly opened pitchers were found to be the most intensely blue-fluorescent due to subsequent quenching of trichome fluorescence. This quenching appeared to progress very rapidly in most species, with the fluorescent signal rendered clearly diminished to non-existent within likely no more than a few weeks of pitcher opening. Of the species observed in the wild, this progression was most clearly seen in Heliamphora chimantensis, owing to its vigorous clumping habit. In pitchers of this species in the process of opening, the entire interior fluoresces brightly (Fig. 1C). Fully opened but still very young pitchers also fluoresce, but this is mostly confined to the ring of long hairs just above the fluid level (Fig. 1B). Fully pigmented adult pitchers (otherwise apparently completely functional) generally lack discernible fluorescence under $365 \mathrm{~nm}$ (Fig. 1D). Consequently, only a small fraction of functional pitchers fluoresce at any given time on any given plant (generally up to one pitcher per growth point and, in large clumps, as few as one per several dozen pitchers, as was observed in wild $H$. chimantensis). This probably explains why Hartmeyer et al. (2013) found $H$. minor to be non-fluorescing, despite viewing it under the same UV band as used in the present study (but see Christmann 2016, who briefly commented on transient fluorescence in Heliamphora).

Preliminary observations of cultivated material suggest that trichome fluorescence may be particularly persistent in the stem-forming species of Amazonas state, namely Heliamphora neblinae, $H$. parva, and $H$. tatei (Figs. 8-9, 11D; the fourth species of this group, H. macdonaldae, largely lacks retentive hairs). Cultivated plants of $H$. parva displayed blue fluorescence throughout all their pitchers, including senescent ones (Fig. 9), suggesting that at least in this species fluorescence can persist for months, if not longer.

Fluorescence in Heliamphora sarracenioides was also found to be restricted to freshly opened pitchers, despite this species lacking retentive hairs (Fig. 7).

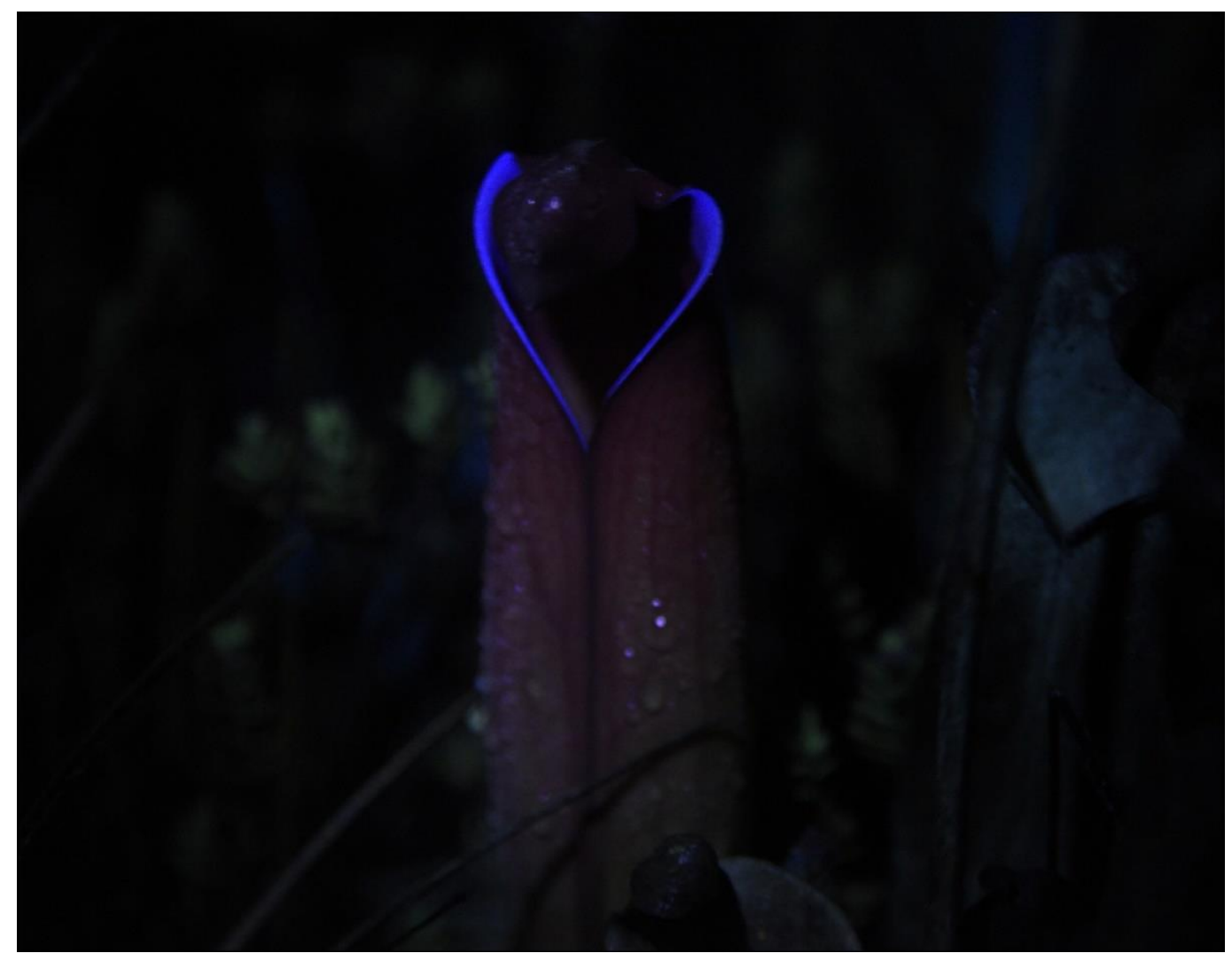

Figure 5: Fluorescent ring of hairs around the rim of a Heliamphora purpurascens pitcher on Ptaritepui. This was the only wild pitcher of this species in which conspicuous fluorescence was observed, despite a number of young and developing pitchers being tested (but see Fig. 11C). 


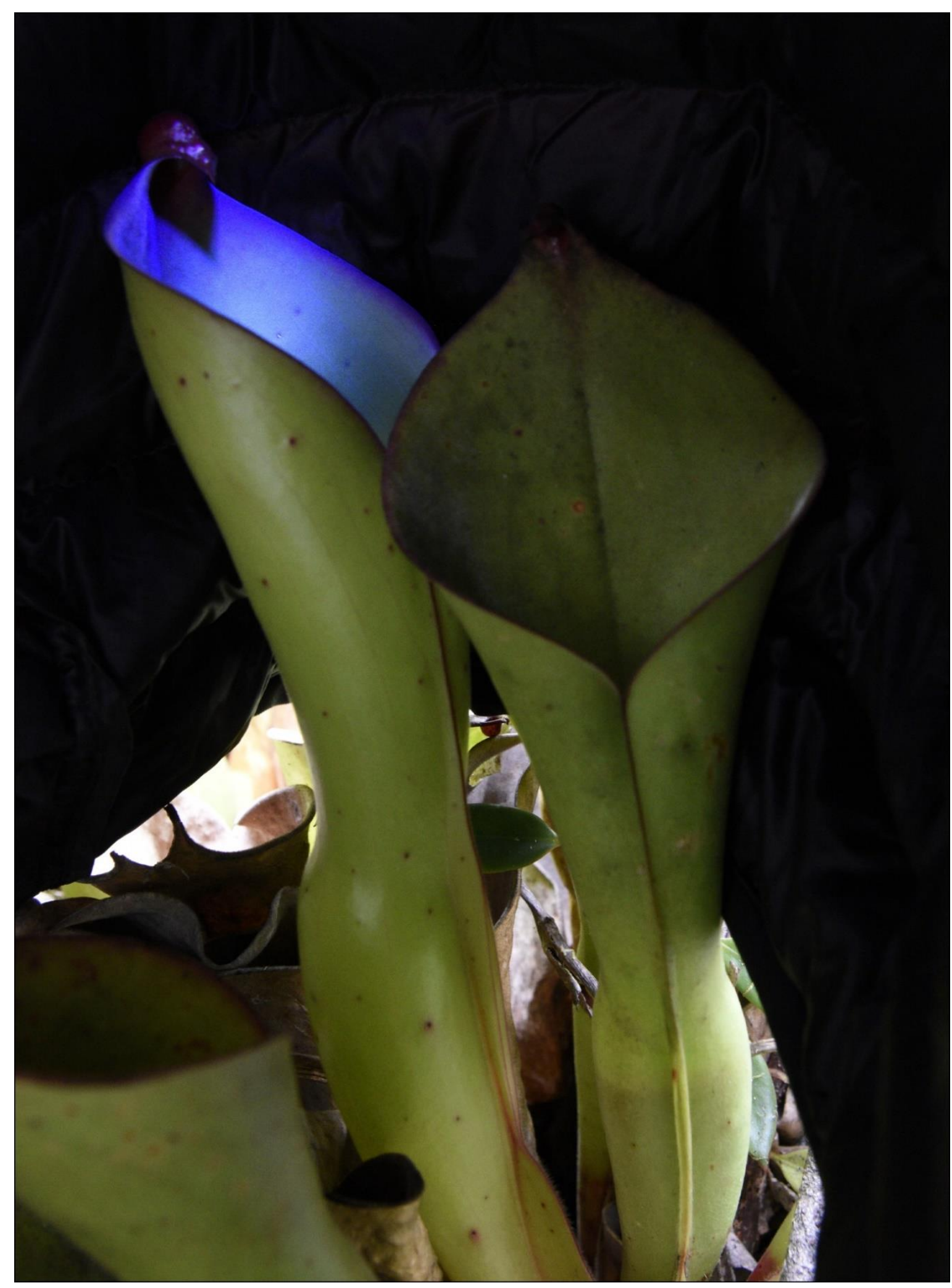

Figure 6: Heliamphora uncinata at its type locality on Amurí-tepui. Strong blue fluorescence is apparent in the freshly opened pitcher; note that the older adjacent pitcher exhibited no perceptible UV-induced fluorescence whatsoever. 


\section{Blue fluorescence is common to other tepui organisms}

Preliminary observations revealed UV-induced blue fluorescence in a range of other tepui plants. On the slopes of Auyán-tepui it was observed in the carnivorous bromeliad Catopsis berteroniana (Fig. 15) and, on the mountain's summit, blue-fluorescing sedges were found (Fig. 3D). On Ptari-tepui, strong blue fluorescence was exhibited by an undetermined Eriocaulaceae and a species of Xyris (Fig. 17A-B). The multicoloured fluorescence of arboreal lichens encountered on the route up Auyán-tepui was particularly striking (Fig. 16). Fluorescence in lichens has been known for many years (Černohorský 1950), but its function (if any) remains uncertain (García-Plazaola et al. 2015).

By chance, a single scorpion was found in association with pitchers of Heliamphora purpurascens on Ptari-tepui (Fig. 17C-D). It was initially stationary in the mouth of a dried pitcher, venturing out onto a live pitcher once disturbed. It is likely to be the first scorpion ever recorded from the summit plateau of Ptaritepui and probably represents a previously undocumented species (C. Brewer-Carías, J.A. Ochoa \& F.J.M. Rojas-Runjaic, pers. comm.; see Ochoa \& Rojas-Runjaic 2019). Scorpions, which have long been known to exhibit brilliant cyan-green fluorescence under UV light (the function of which, if any, is unknown; though see Gaffin et al. 2012), are not uncommon on tepui summits and are among the animals most likely to be encountered during night-time fluorescence studies. Interestingly, scorpions occasionally fall prey to Heliamphora (Jaffe et al. 1992).

\section{Discussion}

\section{Retentive hair fluorescence in Heliamphora: a biosignal?}

The brilliant blue fluorescence of the retentive hairs is instantly captivating (Fig. 18). Since retentive hairs are the primary structures involved in prey trapping, the question naturally arises: might they also play a role in prey attraction?

To be involved in biosignalling, the wavelengths of fluoresced light must lie within the sensitivity range of the putative target species. Most insects are trichromats, having visual sensitivity maxima in the UV, blue, and green wavebands, this being the ancestral state of the group (Briscoe \& Chittka 2001; Song \& Lee 2018). However, when it comes to ants, which make up the bulk of prey caught by Heliamphora in the wild (Gonzalez et al. 1991; Jaffe et al. 1992; Fleischmann \& McPherson 2009), UV-green dichromacy appears to be the norm, with some limited evidence for UV-blue-green trichromacy (Aksoy \& Camlitepe 2018). This would argue against a role in prey attraction, at least of ants, though in any case ants would seem an unlikely biosignalling target given their terrestrial nature and primary reliance on other sensory modalities. Further casting doubt on this idea is the brief temporal window of fluorescent activity, particularly when compared to the functional lifespan of an individual pitcher (many months to several years; pers. observ.). On the other hand, assuming the ants can see the fluoresced wavelengths, early attraction might be sufficient, with subsequent capture facilitated by pheromone-based foraging trails. If the plant-ant interaction is a simple predator-prey relationship, attraction to blue fluorescence should not be selected for (unless a form of aggressive mimicry is involved), but if at the level of the ant colony it represents a mutually beneficial interaction (cf. Joel 1988) then this would be expected.

It is noteworthy that blue fluorescence seems to persist much longer in the stem-forming species of Amazonas state, which appear to be specialised to catching flying prey. Jaffe et al. (1992) found that for both Heliamphora tatei from Cerro Huachamacari and $H$. neblinae (then lumped with $H$. tatei) from Cerro Aracamuni, flying insects constituted a higher proportion of prey than seems to otherwise be the norm in the genus. Only in these taxa was the proportion of pitchers with ant prey lower or the same as the proportion with non-ant prey. This is perhaps not surprising as these species are usually the tallest element in their habitats (Jaffe et al. 1992). Attraction of flying insects by fluorescence seems more likely than that of ground-dwelling insects such as ants, given its increased visibility from the air, where it could presumably be detected from much greater distances (perhaps even as compared to other sensory modalities such as olfaction; cf. Brewer-Carías 1972, 1973; Jaffe et al. 1995). Nevertheless, most visiting arthropods have been observed to land directly on the nectar spoon or at least in its close vicinity (McPherson et al. 2011), strongly implicating olfaction as the final cue. 

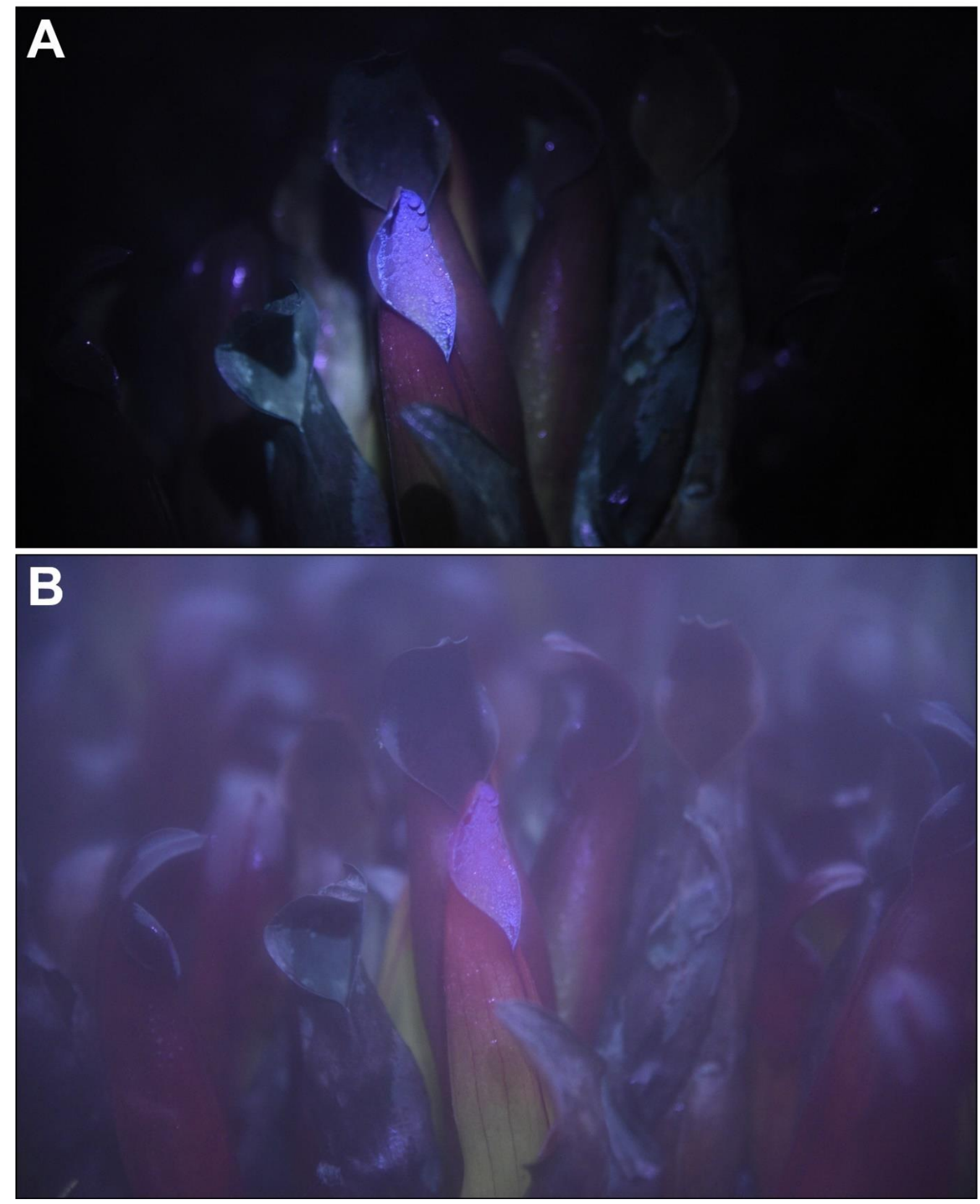

Figure 7: A freshly opened Heliamphora sarracenioides pitcher on the summit plateau of Ptaritepui, (A) showing modest UV-induced fluorescence throughout the hairless interior surface (photo taken at 5:26 am local time). (B) The same clump photographed 14 minutes later (5:40 am local time). At this point, ambient light is already beginning to overwhelm the fluorescent signal (at least as perceived by human eyes). 


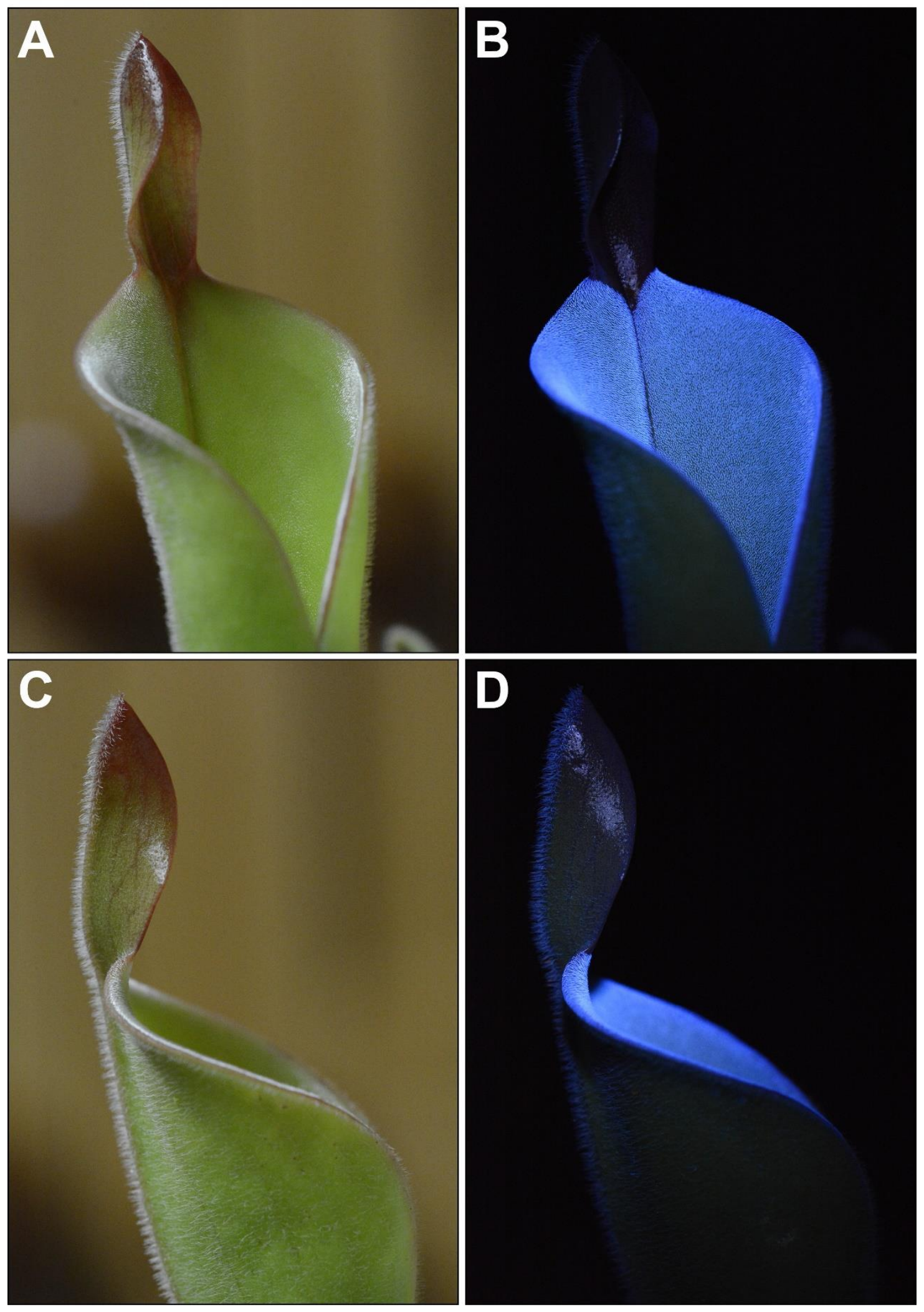

Figure 8: Heliamphora parva under white light and under UV in the dark. Note the modest blue fluorescence from the hairs of the exterior pitcher midrib (D). 


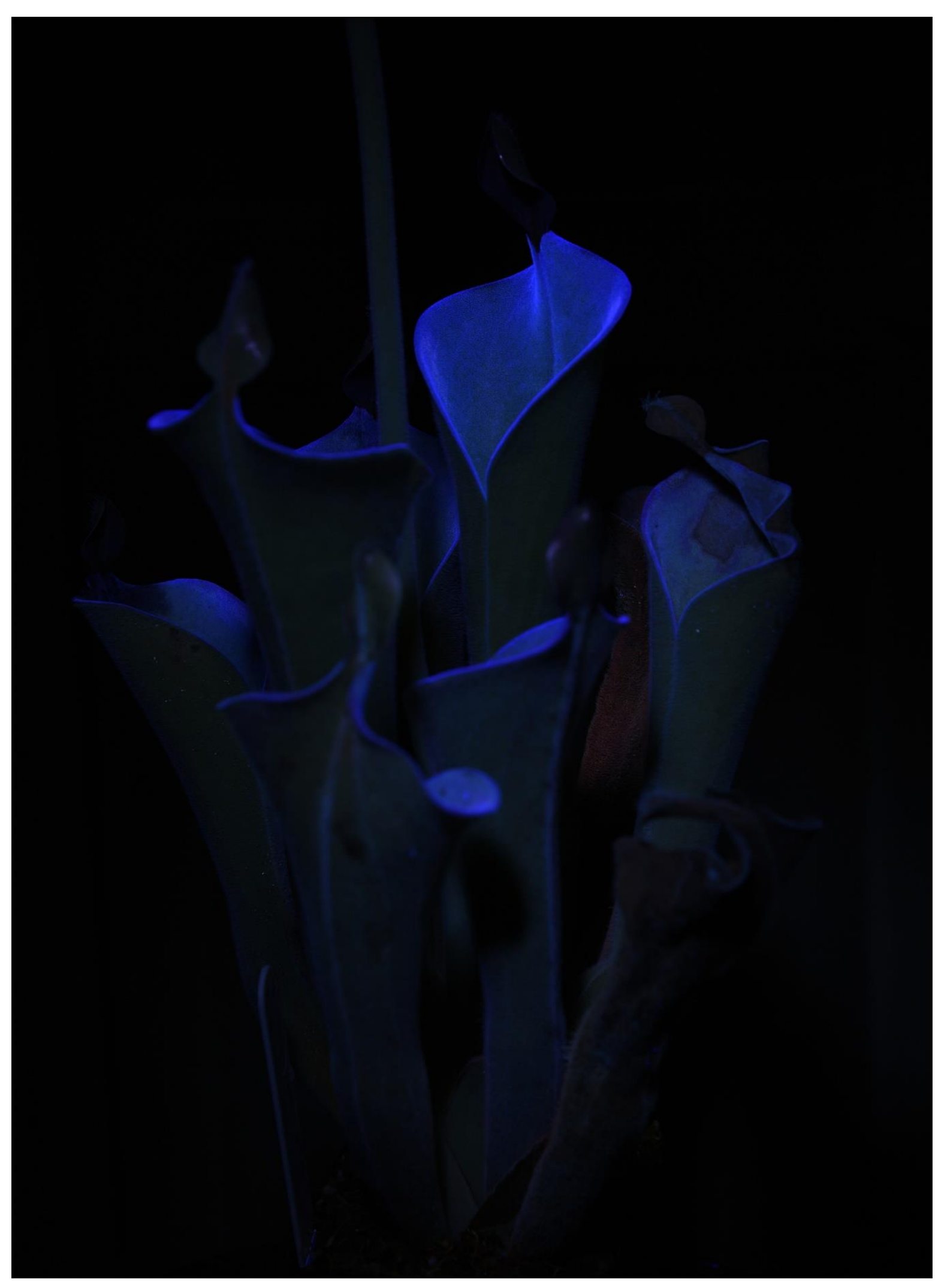

Figure 9: Single growth point of Heliamphora parva, showing persistent blue fluorescence even in senescing pitchers. 
Another possible function of retentive hair fluorescence might be early recruitment of pitcher inquilines. Though comparatively little research has been done on the aquatic insect communities of Heliamphora, the plants are known to commonly host mosquito (Wyeomyia spp.) and midge larvae, all of which are apparently obligate pitcher inhabitants (Zavortink 1985; Barrera et al. 1989; Studnička 2003). These likely benefit the plant by making nutrients from captured prey more readily available as part of a mutualistic relationship (Adlassnig et al. 2011). One can see how it might be advantageous for ovipositing insects to be able to identify newly opened pitchers to ensure that their offspring (a) complete the aquatic stage of their life cycle before conditions deteriorate due to pitcher senescence and (b) are able to exploit the higher input of prey (and consequently increased number of lower-trophic-level inquilines) at the beginning of a pitcher's functional life and thereby avoid increased mortality associated with food limitation (cf. Bradshaw 1983). Likewise, the plant would presumably stand to benefit from having larval hatching coincide with the onset of prey acquisition. Indeed, it has been shown that mosquito (but not midge) oviposition overwhelmingly takes place in the very youngest Heliamphora leaves, even prior to the commencement of prey capture (Barrera et al. 1989; Jaffe et al. 1992). A similar pattern has been consistently observed in the North American Sarracenia purpurea (Fish \& Hall 1978; Bradshaw 1983; Nastase et al. 1995; Bergland et al. 2005; Miller \& terHorst 2012), which also hosts a Wyeomyia species in its pitchers, though in $S$. purpurea the inquiline mosquitoes are apparently attracted by chemical cues (Mogi \& Mokry 1980; Istock et al. 1983). ${ }^{2}$ Interestingly, colour appears to be a factor in the selection of ovipositional sites by at least some bromeliad-breeding Wyemoyia (Frank 1986), and multiple studies have demonstrated the same for other mosquitoes (see Allan et al. 1987). Mosquitoes, like most insects, are sensitive to blue light and could therefore plausibly see blue fluorescence. Indeed, Williams (1962) showed that females of a certain North American tree hole-breeding species (Aedes triseriatus, now Ochlerotatus triseriatus) were specifically attracted to blue wavelengths when selecting sites for egg deposition.

\section{Other sources of blue fluorescence in Heliamphora}

External trichomes were also found to be blue-fluorescent (Fig. 8D), though to a far lesser degree than retentive hairs. An ecological function seems unlikely, but perhaps the prominent tuft of white hairs found on top of the nectar spoon in species such as $H$. ciliata and H. ceracea (the latter also highly UV-reflective; cf. McPherson et al. 2011: fig. 54) serves as a visual guide, leading visitors to the nectar spoon in complement with olfactory cues. It should be noted that if these trichomes are materially identical to the retentive hairs and exhibit similar age-related fluorescence loss, then the latter could be expected to commence much earlier in external hairs (i.e. prior to pitcher opening).

The blue fluorescence of Heliamphora is not limited to hairs, being also present in nectaries and in nectar itself, these usually being largely confined to the nectar spoon. Blue autofluorescence of Heliamphora lid nectaries has previously been noted in passing by Płachno et al. (2007), and Moran (1991) noted the same for Nepenthes lid and peristome nectaries. Blue nectar fluorescence is widespread among plants (Thorp et al. 1975; Roshchina 2008) and it would seem unlikely to be biologically relevant in Heliamphora given its small contribution to total emerging light. As such, species whose blue fluorescence is almost entirely restricted to the nectar spoon, such as $H$. glabra and $H$. macdonaldae, are improbable candidates for fluorescent biosignalling.

Heliamphora sarracenioides is unique in that it completely lacks a nectar spoon or analogous structures (viz. the 'nectar bubble' of $H$. exappendiculata), instead having a roughly even distribution of relatively large $(\leq 0.2 \mathrm{~mm})$ nectar glands throughout the upper portion of its inner surface (Carow 2005; Carow et al. 2005). This species is also unusual in that the pitcher interior typically matures to a much darker (often near-black) colour than the exterior (the reverse is true in most other pitcher plants; McPherson et al. 2011), and its pitchers produce a distinct cocoa-like fragrance, quite unlike the honey-like scent of other Heliamphora (Fleischmann \& McPherson 2009). It is possible that the unusual structure and colouration of

\footnotetext{
${ }^{2}$ Istock et al. (1983) argued against visual cues for inquilines in Sarracenia purpurea on the basis of simple tests involving coloured paper hoods (green, green and purple-veined, and white) attached to the tops of jars, though they acknowledged that these made for a "weak" experiment.
} 
the pitcher interior is an adaptation to maximise its efficiency as an osmophore: a large nectariferous surface that absorbs as much visible light as possible and thereby effectively volatilises the overlying chocolatey odorant. Again, the modest fluorescence of the inner surface (Fig. 7) seems likely to be incidental.

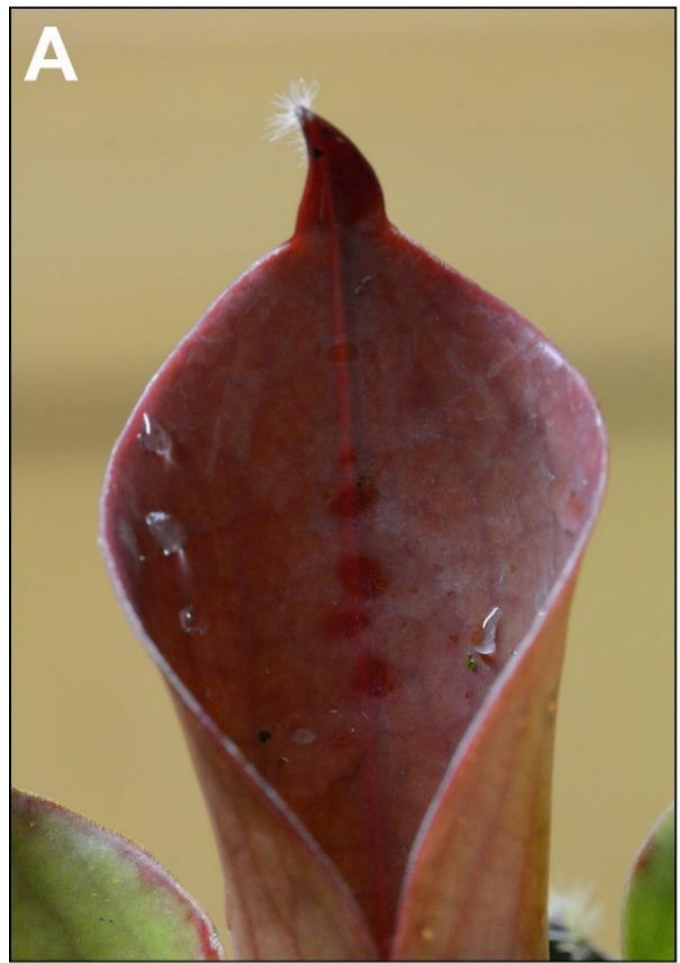

\section{B}
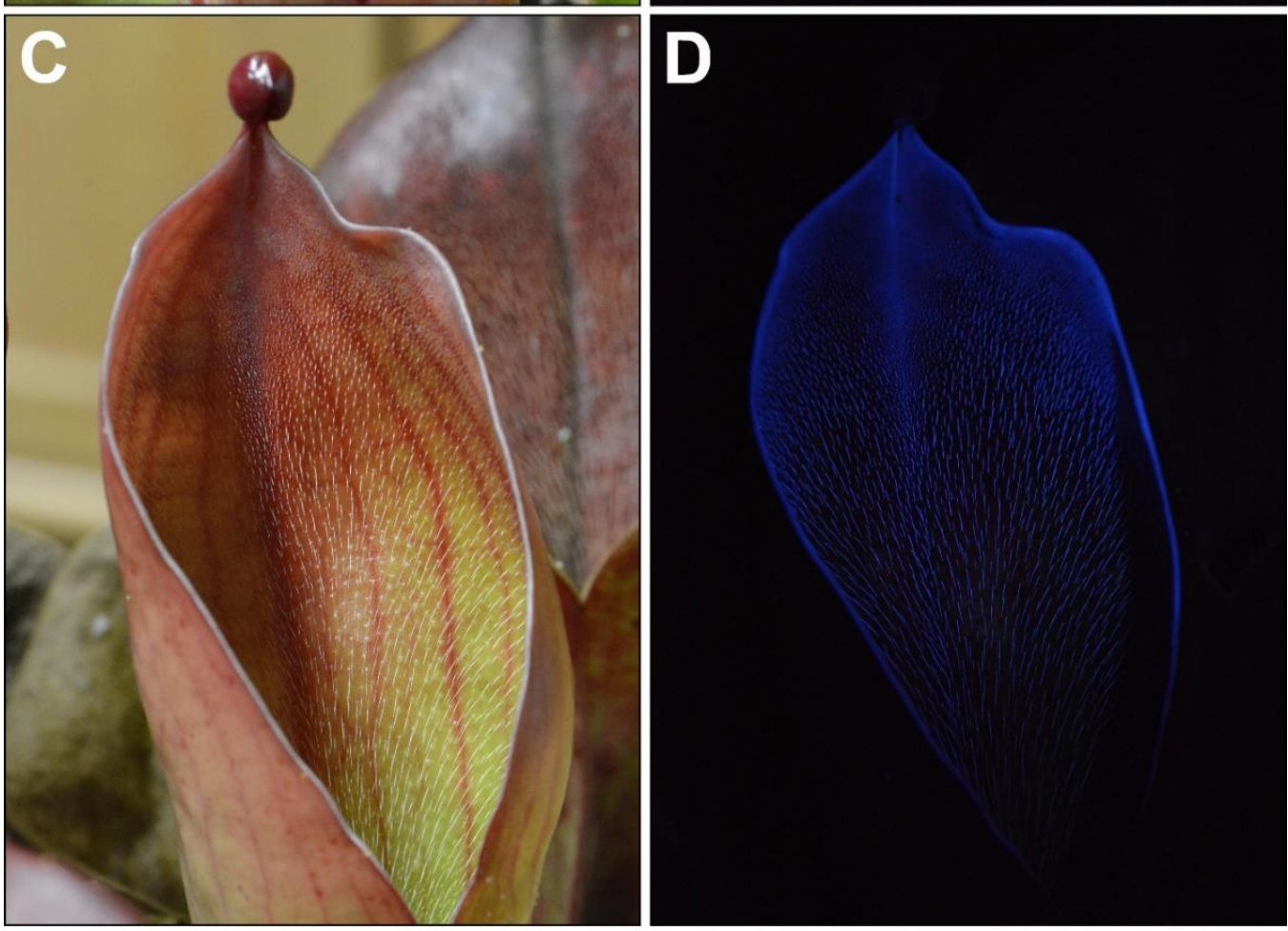

Figure 10: Heliamphora ceracea $(\mathrm{A}-\mathrm{B})$ and $H$. ionasi $(\mathrm{C}-\mathrm{D})$ under white and UV illumination, showing nectary and trichome fluorescence, respectively. 


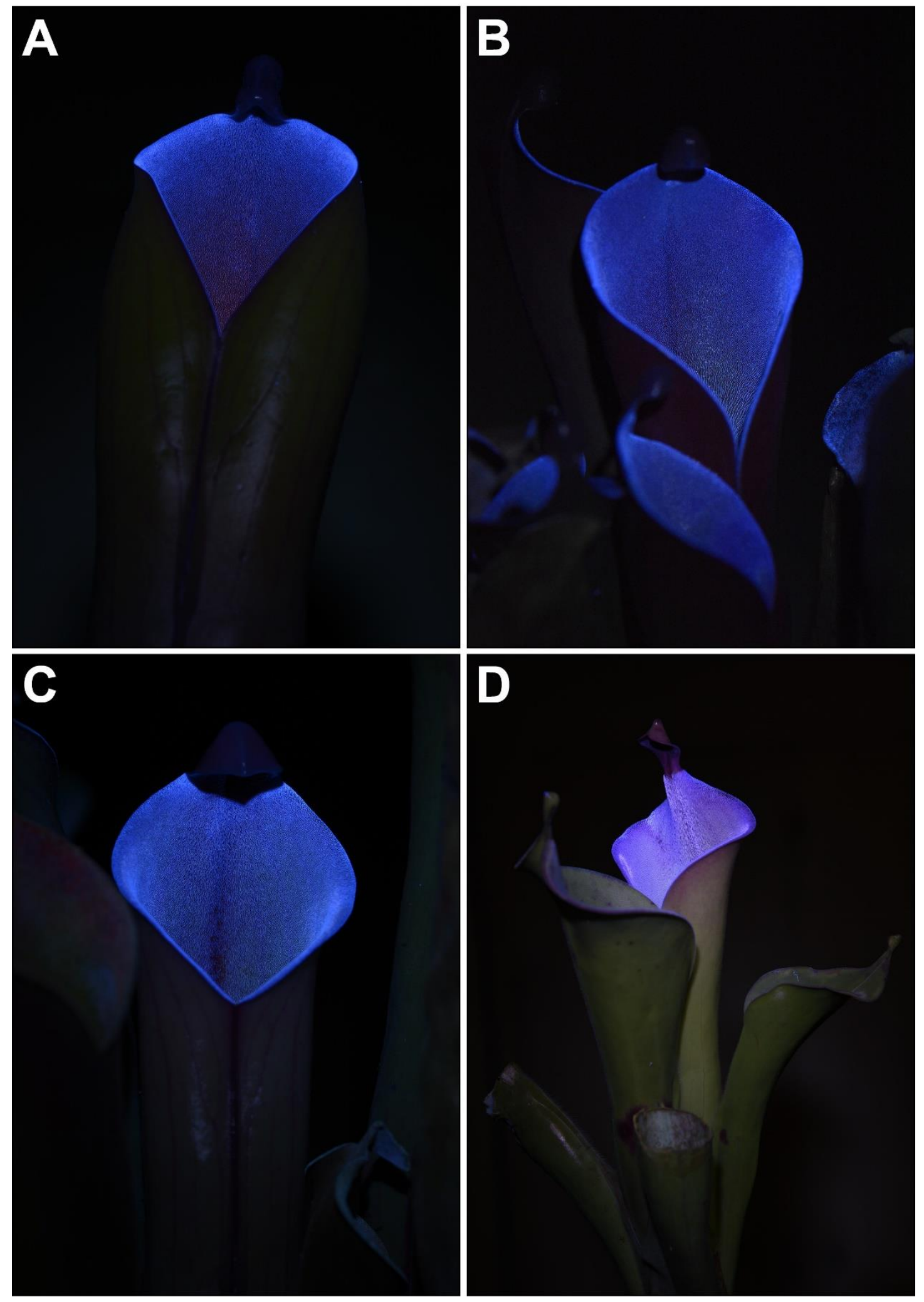

Figure 11: Fluorescence in cultivated plants of Heliamphora folliculata (A), $H$. huberi (B), $H$. purpurascens $(\mathrm{C})$, and $H$. tatei $(\mathrm{D})$. Note the increasing contribution of red (likely chlorophyllderived) fluorescence towards the interior of the $H$. folliculata pitcher. 

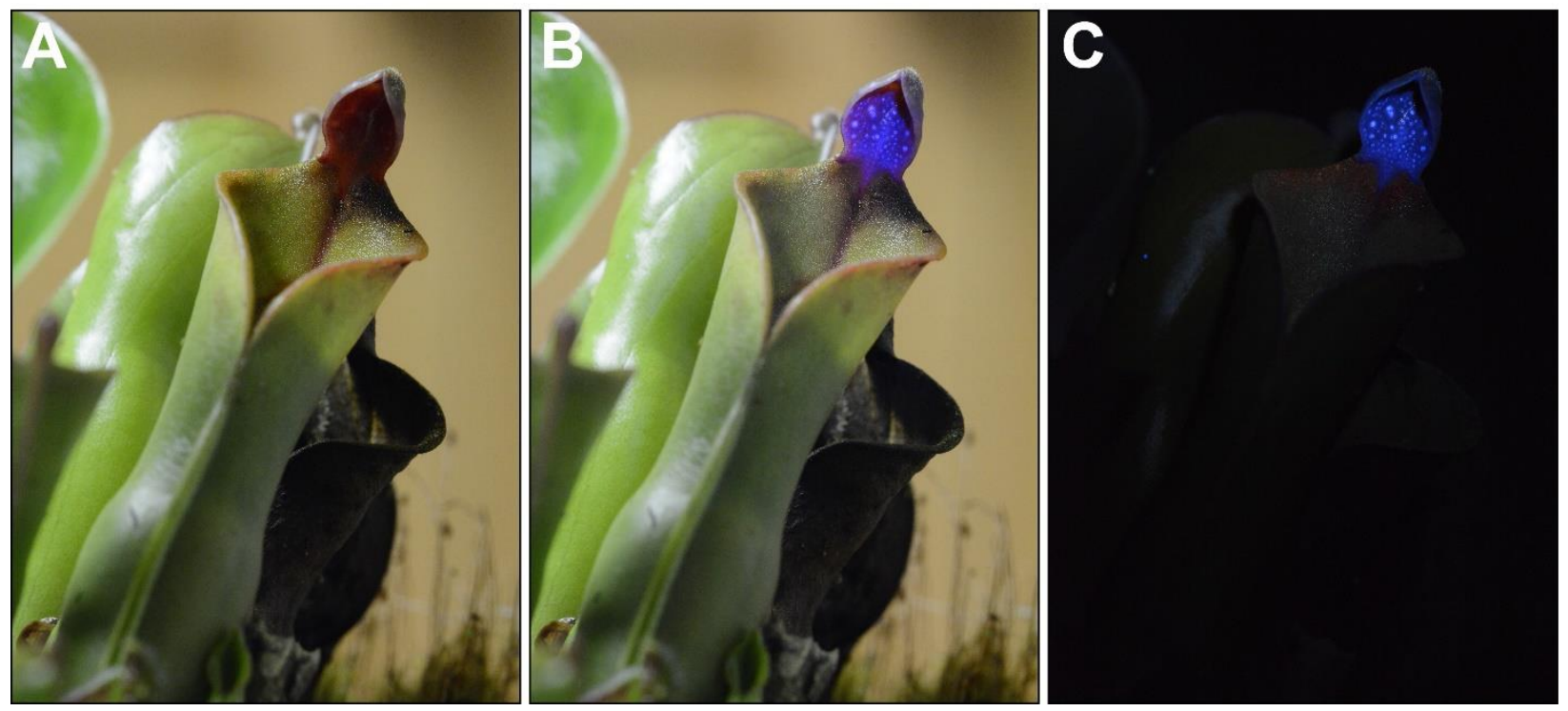

Figure 12: Cultivated plant of Heliamphora nutans from Yuruaní-tepui. This old pitcher lacked trichome fluorescence but showed strong nectar-derived fluorescence. The photos were taken under white light (A), a combination of white and UV light (B), and UV light alone (C).

\section{Fluorescence in Heliamphora: a caveat}

Caution should be exercised whenever attempting to assign ecological importance to fluorescent phenomena, since it is tempting to view them solely through the prism of human visual perception, which often differs markedly from that of the putative target species. ${ }^{3}$ This is especially true when viewing UVinduced visible fluorescence at night under a high-power UV source, rather than in a biologically relevant context (Marshall \& Johnsen 2017). The fluorescent 'glow' may appear impressive, but that is because the powerful excitatory (UV) light is invisible to us and so the comparatively weak fluoresced light is sensitising eyes accommodated to darkness; when viewed under natural light the fluorescence is likely to become imperceptible (again, to us!).

The biological 'impracticality' of UV-induced visible fluorescence is down to both the inherent inefficiency of the fluorescence conversion process and to the low intensity of UV radiation reaching the Earth's surface as compared to visible light (the photon flux density of the former being around $5 \%$ of the latter; García-Plazaola et al. 2015). It is also important to remember that since UV radiation is visible to most insects, it can be utilised for biosignalling not only through fluorescence but also (much more efficiently) through reflectance. Similarly, a biosignal in the visible spectrum could be created by simply reflecting visible light. Indeed, Heliamphora pitchers exhibit clear UV contrast patterns, the bright (UVreflective) pitcher interior being conspicuous against the dark (UV-absorbent) exterior (Joel 1983; Joel et al. 1985; Juniper et al. 1989; McPherson et al. 2011). ${ }^{4} \mathrm{UV}$ reflectance patterns have also been reported from other pitcher plants, as well as from carnivorous plants more widely (Joel 1983; Joel et al. 1985; Juniper et al. 1989; Moran 1991; Glossner 1992; Cross et al. 2019). Nepenthes, for example, have been shown to employ UV patterns in their pitchers to attract prey (Moran 1996; Moran et al. 1999), these being lost when alternative nitrogen sources are exploited (Clarke et al. 2011).

\footnotetext{
${ }^{3}$ Even with respect to reflectance patterns, those in the UV range have often been singled out as being of particular importance in the visual stimulation of insects, though in many cases they are likely no more significant than signals in the visible spectrum, the particular attention afforded them being due to anthropocentric bias (Kevan et al. 2001).

${ }^{4}$ It is curious that it is the ostensibly UV-reflective part of Heliamphora pitchers that exhibits UV-induced fluorescence, the reverse of the expected situation (and that in Nepenthes, where the comparatively UV-absorbent peristome fluoresces; Moran 1991). The relationship between pitcher age and UV reflectance requires further study.
} 

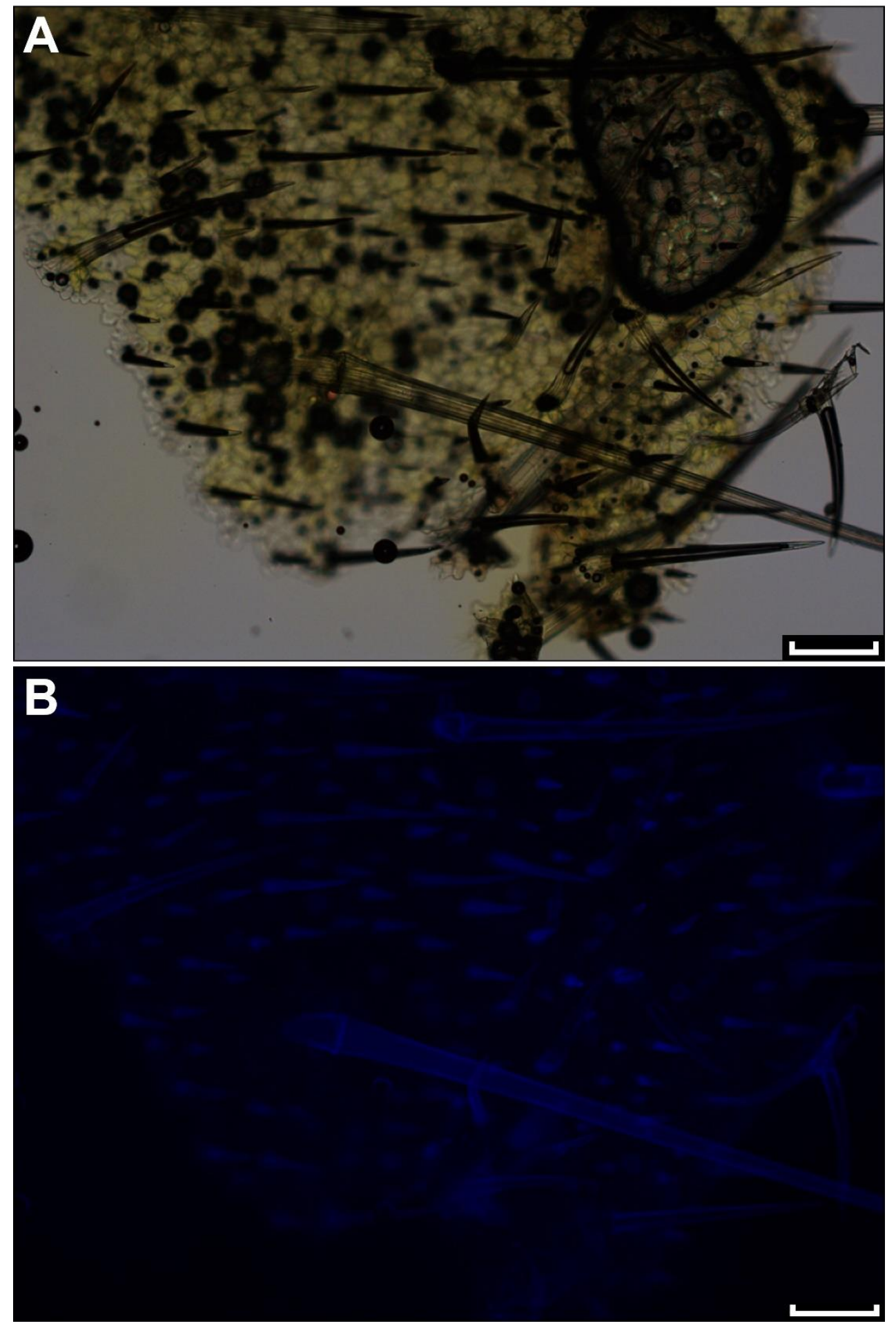

Figure 13: Thin slice of the interior surface of a young Heliamphora pulchella pitcher. At least two discrete size classes of trichomes are readily discernible. (A) As viewed under bright-field microscopy. (B) The same piece of tissue viewed under fluorescence microscopy with a DAPI filter cube (specimen excited by UV light and emitted light filtered to blue). It is clear that the trichomes are the only structures exhibiting significant blue fluorescence under this UV excitation range, the surrounding tissues remaining dark. Scale bars $=250 \mu \mathrm{m}$. 


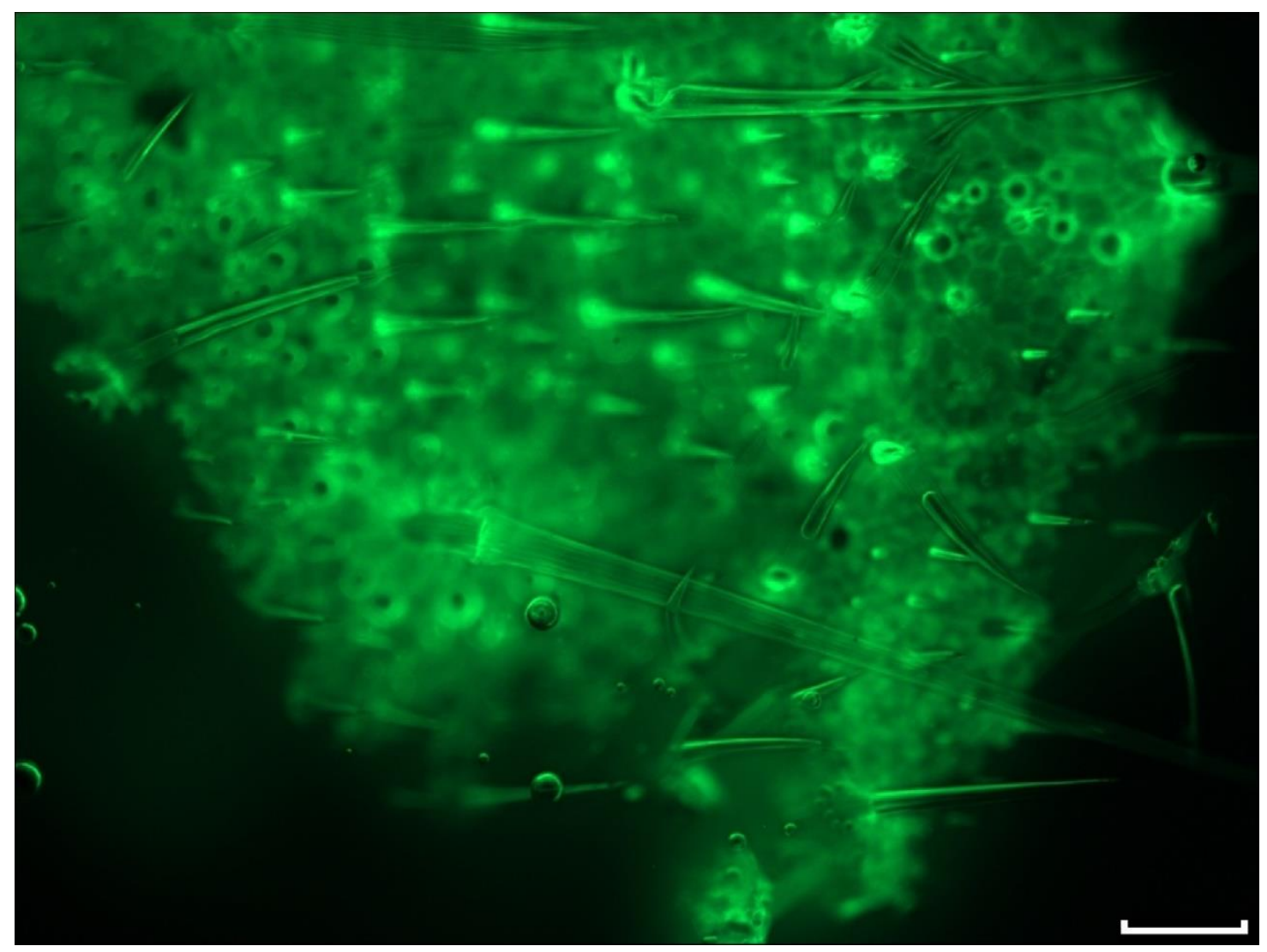

Figure 14: Viewed under the GFP filter cube the situation is reversed, the fluorescence of the epidermis being far more intense than that of the trichomes (which are illuminated by exogenous green light rather than fluorescing themselves). Scale bar $=250 \mu \mathrm{m}$.

Of course, reflection and fluorescence signals need not be mutually exclusive, and it is possible that they act in concert to enhance or broaden the range of emerging (reflected plus fluoresced) light that corresponds to the visual sensitivity maxima of the intended recipients (cf. Guerrero-Rubio et al. 2020). Here it is important to reiterate that intensely blue-fluorescent Heliamphora trichomes look qualitatively different even under normal daylight illumination, though of course this could be due to factors other than blue fluorescence (e.g. higher reflectance across the visible spectrum). Interestingly, the Heliamphora species of the northern part of the Eastern Tepuis chain (viz. H. arenicola, H. elongata, H. ionasi, and H. nutans, which form an exclusive clade; Liu \& Smith 2020) often have golden retentive hairs, a trait apparently unique to this group (pers. observ.). The reasons for this warrant further investigation.

\section{Fluorescence in other carnivorous plants}

Among carnivorous plants, UV-induced blue fluorescence has previously been reported from Dionaea, Nepenthes, Sarracenia, certain Drosera, and Brocchinia reducta (Moran 1991; Kurup et al. 2013; Hartmeyer et al. 2013; Williams \& Hartmeyer 2017). In a widely reported study, the peristomes of selected Nepenthes and Sarracenia species and the traps of Dionaea were found by Kurup et al. (2013) to exhibit blue fluorescence under $366 \mathrm{~nm}$ UV light. The authors claimed to show that this fluorescence is key to attracting arthropod prey and the study was cited by Marshall \& Johnsen (2017) as one of the best-supported examples of putative fluorescent biosignalling. However, their manipulation experiment with Nepenthes khasiana (see Haridas 2014), which was claimed to show drastically reduced prey attraction upon masking of blue fluorescence, failed to adequately control for confounding variables. Firstly, the authors did not consider how the masking agent (an acetone extract of the internal 'waxy zone') might affect the plant's 
other (well established) sensory cues, such as reflectance patterns (particularly in the UV part of the spectrum, these not being readily apparent) and scent. Even assuming constancy of the attraction regime absent blue fluorescence (extremely unlikely), there remains the problem that the authors did not directly demonstrate a change in visitation rates, only in capture rates. Covering the peristome in a masking substance undoubtedly altered its trapping efficiency by creating a physical barrier between the insects' attachment organs and the peristome surface (which has a specialised microstructure conferring hydrophilic and anisotropic properties; Bohn \& Federle 2004; Bauer \& Federle 2009), making prey counts wholly unsuitable as a proxy for visitation frequency.

Kurup et al. (2013) also reported blue, UV-induced fluorescence in Nepenthes pitcher fluid, which intensified greatly following chitin induction (simulating prey trapping). As pointed out by Hartmeyer $e t$ al. (2013), this could simply be due to contamination by nectar from the peristome. Kurup et al. (2013) did not make clear whether it is the nectar or the peristome tissue itself that fluoresces (Horner et al. 2018), but Moran (1991), who was perhaps the first to document the UV-induced blue fluorescence of Nepenthes peristomes, found it was localised primarily to the walls of parenchymal cells subjacent to the epidermis.

Kurup and colleagues even speculated about the possibility that Bornean Nepenthes known to form mutualistic relationships with bats, rats and tree shrews (viz. N. hemsleyana, N. lowii, N. macrophylla, and N. rajah) could be luring them with blue fluorescence (Kurup et al. 2013; Stromberg 2013). However, experimental work to date has instead implicated colour contrast signals in the visible (especially green) spectrum (Moran et al. 2012). In summary, the involvement of blue fluorescence in prey or mutualist attraction by carnivorous plants has yet to be adequately demonstrated.
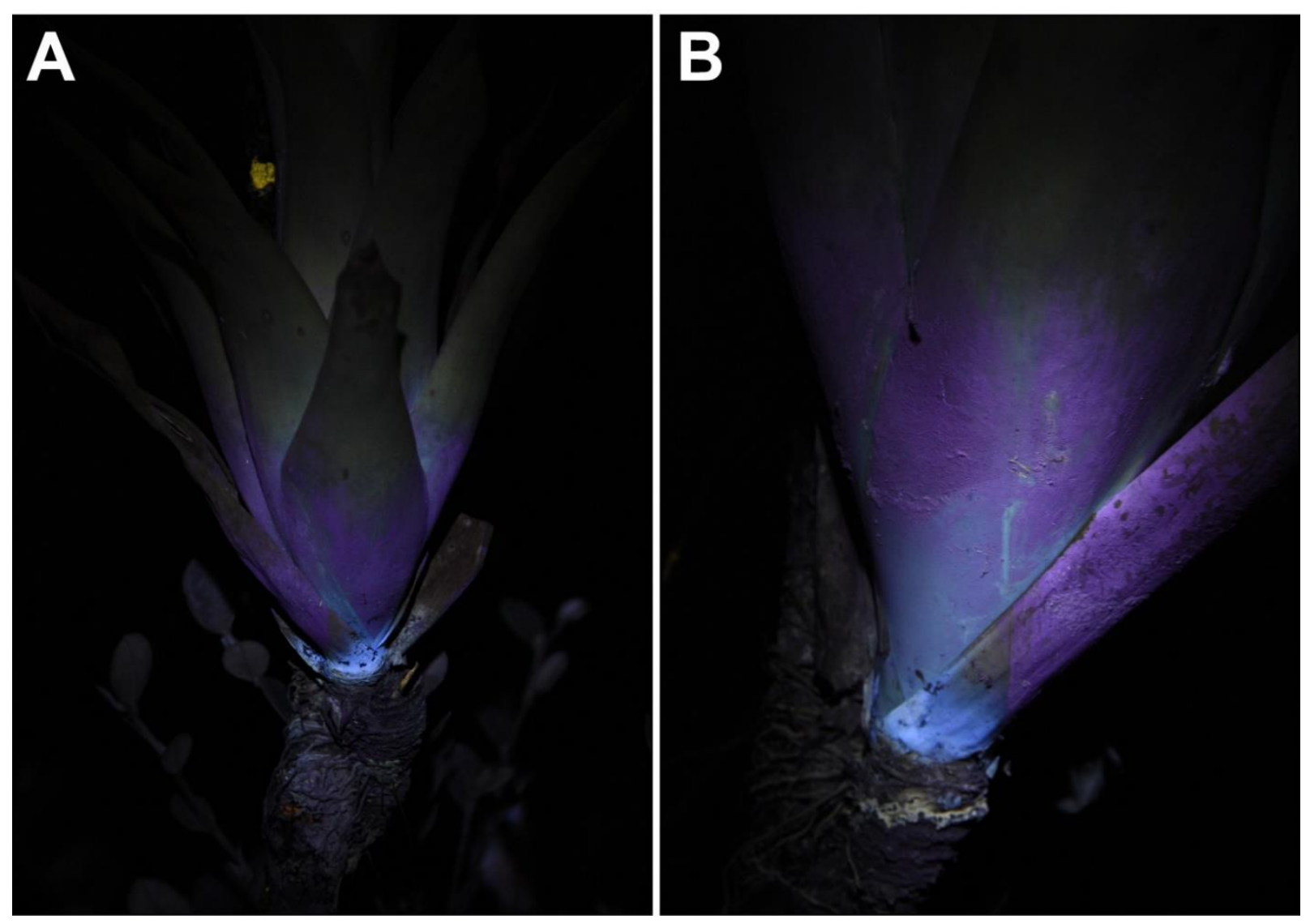

Figure 15: In the carnivorous bromeliad Catopsis berteroniana, the leaf bases show blue fluorescence that contrasts sharply with the violet fluorescence of the overlying glaucous bloom. This specimen was photographed on the way up Auyán-tepui. 


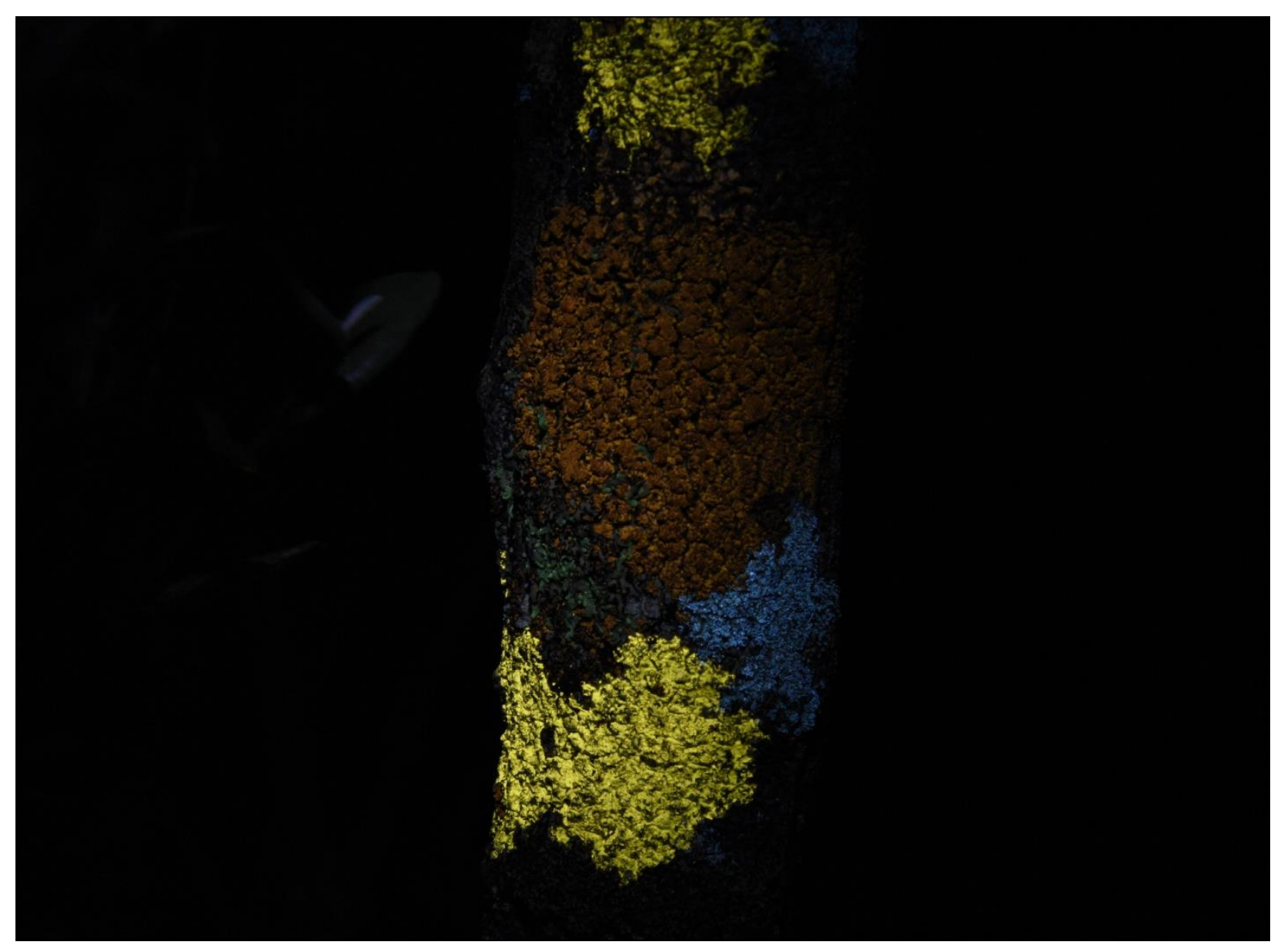

Figure 16: Striking yellow, auburn, green and blue fluorescence of assorted lichens growing on a tree colonised by Catopsis berteroniana, on the lower slopes of Auyán-tepui.

\section{Evidence for fluorescent biosignalling more generally}

Studies of fluorescent biocommunication have thus far been largely confined to marine organisms, including proposed examples among hydrozoans (Haddock et al. 2005; Haddock \& Dunn 2015), mantis shrimps (Mazel et al. 2004), and fishes (Michiels et al. 2008; Sparks et al. 2014) including sharks (Gruber et al. 2016). With increasing water depth, ambient light becomes essentially monochromatic (blue) and therefore fluorescence at longer wavelengths (e.g. green or red) is necessarily conspicuous, providing it is within the visual sensitivity range of the target species (Bielmeier 2009). Demonstrating ecologically relevant fluorescence in the chromatically complex terrestrial environment is far more difficult, though there are putative or speculative examples from animals as phylogenetically disparate as spiders (Andrews et al. 2007; Lim et al. 2007; Brandt \& Masta 2017), scorpions (Gaffin et al. 2012), butterflies (Vukusic \& Hooper 2005), frogs (Taboada et al. 2017a, b), salamanders (Lamb \& Davis 2020), chameleons (Prötzel et al. 2018), parrots (Arnold et al. 2002), and flying squirrels (Kohler et al. 2019). The adaptive relevance of many of these has been questioned as the associated studies often rely on only circumstantial evidence (Johnsen 2012; Marshall \& Johnsen 2017).

Fluorescent biosignalling in plants remains controversial. Though fluorescent patters are widespread in flowers (Rørslett 2006; Fukui et al. 2017), and various fluorescing parts thereof-including nectar (Thorp et al. 1975; Davies et al. 2005), petals (Gandía-Herrero et al. 2005a, b) and their associated trichomes (Lam et al. 1980), pollen, and anthers (Mori et al. 2018; Mori \& Hirai 2019) - have been proposed as cues for pollinators, this has been challenged on the grounds that the putative signals are too weak to be readily 
perceptible by pollinators in natural settings (Kevan 1976; Iriel \& Lagorio 2010a, b; Lagorio et al. 2015; van der Kooi et al. 2019). Having reviewed a variety of fluorescing species, Iriel \& Lagorio (2010b) concluded that floral fluorescence was unlikely to be ecologically relevant as its intensity was too low compared to that of reflected light and likely to be overwhelmed by it. The highest fluorescence quantum yield value calculated by the authors for any flower part was only 0.03 (i.e. only $3 \%$ as many fluorescence photons emitted as excitatory photons absorbed). As a result, diffuse reflectance exceeded the intensity of fluorescence peaks in the same spectral regions by at least $c a$. 20 times, and often by more than two orders of magnitude (Iriel \& Lagorio 2010b).

Nevertheless, proposals for fluorescence-based biocommunication in plants abound. Sabulal et al. (2013) published a paper on UV-induced blue fluorescence in grasses, which they proposed might act as a visual cue for pollinators, seed dispersers, or even seed predators. These speculations, for which the authors provided no experimental support, are even more problematic than their conclusions regarding carnivorous plants (see Holovachov 2015b). In another example, blue fluorescence in banana skin has been suggested as an indicator of ripeness perceptible to frugivorous animals (Moser et al. 2008, 2009). Again, experimental evidence is lacking. Mori et al. (2018) carried out studies with live honeybees that seemed to support the involvement of fluorescence in pollinator biosignalling, though notably the authors did not conduct behavioural assays with real plants but rather filter paper discs containing blue-fluorescing chlorogenic acid (this being one of the main fluorescent phytochemicals identified in the species tested). Even so, it has been shown that bees are capable of very fine colour discrimination (Dyer \& Neumeyer 2005) and it is conceivable that under certain conditions fluorescence could function as a signal amplifier or, if in a spectral region of very low reflectance, even as a signal in its own right (Iriel \& Lagorio 2010b; Guerrero-Rubio et al. 2020).
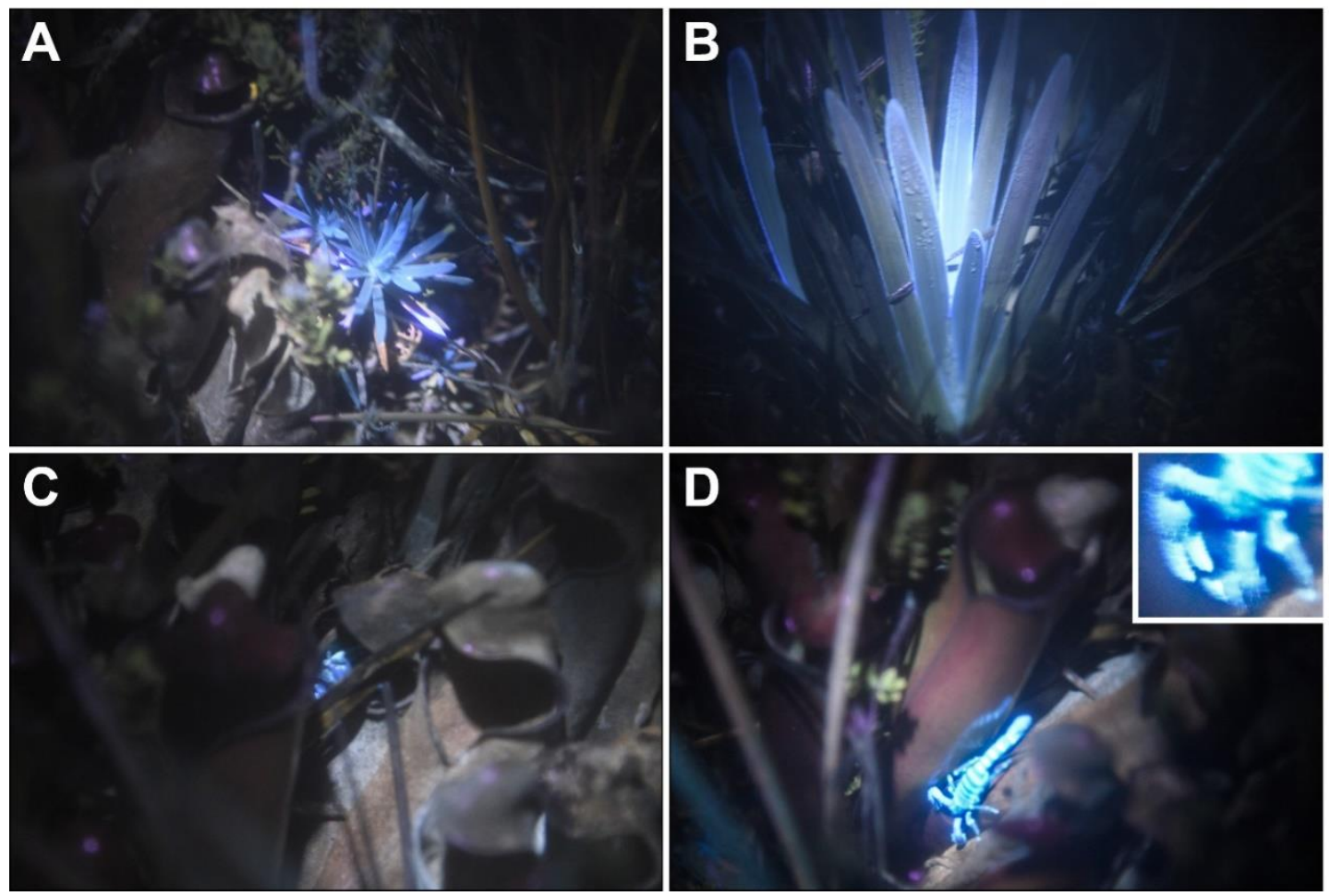

Figure 17: Blue-fluorescing flora and fauna on the summit plateau of Ptari-tepui: (A) an undetermined Eriocaulaceae (note the comparatively inconspicuous Heliamphora purpurascens pitchers to the left); (B) Xyris sp.; (C-D) a chactid scorpion, likely an as-yet undescribed species of Taurepania, among pitchers of $H$. purpurascens, shown as originally found $(\mathrm{C})$ and after being disturbed (D); note the conspicuously hairy chelipeds (pincer-bearing forelimbs; inset). 
For fluorescence to be considered a potential biosignal it should be demonstrated that a) it corresponds to the visual sensitivity range of the putative target species; b) the contribution of fluoresced light, under natural conditions, is sufficient as a fraction of total emerging (reflected plus fluoresced) light in the relevant waveband to be plausibly detected by the putative target species; and c) controlling for other variables, the experimental removal or attenuation of said fluorescence alters the behaviour of the receiver in a way that is disadvantageous to the emitter (cf. Marshall \& Johnsen 2017; Mazel 2017; Macel et al. 2020). It is also important to consider the relevant illumination regime. While fluorescence may constitute a negligible fraction of emerging light in, say, a daylight scenario, this might not be so during night-time or twilight (Johnsen et al. 2006, Taboada et al. 2017a).

\section{Fluorescence in Heliamphora: other possible explanations}

Fluorescence need not be ecologically relevant to have adaptive value. One possibility is that it is photoprotective, converting damaging UV-A radiation into less energetic blue wavelengths. This has been suggested to take place in leaves (Lang et al. 1992; Lichtenthaler \& Schweiger 1998), including specifically through blue-fluorescing trichomes (Lang \& Schindler 1994), as well as in plant reproductive structures, where mutagenesis would be particularly harmful (Sabulal et al. 2013; Mori et al. 2018). Alternatively, blue fluorescence might enhance photosynthesis by 'creating' photosynthetically active radiation from otherwise unproductive UV light (Hoque \& Remus 1999). There is evidence for both of these processes in corals (Schlichter et al. 1994; Salih et al. 2000) and it is quite possible that they work in tandem in various green plants and lichens (García-Plazaola et al. 2015). In Heliamphora, however, neither role seems likely given the highly transient nature of the blue fluorescence and the small fraction of the total pitcher surface that fluoresces.

Finally, it is important to remember that many natural compounds and materials autofluoresce as a byproduct of their chemical makeup. It is entirely possible that the observed fluorescence in Heliamphora is merely an epiphenomenon: an incidental, non-adaptive property of phytochemicals that evolved to serve some unrelated function.

\section{Chemical basis of observed fluorescence}

Blue fluorescence is common throughout the plant kingdom (Rost 1995; Roshchina 2008) and present in both monocots and dicots, with the former generally showing greater emission intensities (Lichtenthaler \& Schweiger 1998; Johnson et al. 2000). Common plant constituents that exhibit blue fluorescence include ferulic acid (emission maximum: 400-480 nm), rosmarinic acid $(440-450 \mathrm{~nm}), p$-coumaric acid (415-445 $\mathrm{nm}$ ), chlorogenic acid (ca. $440 \mathrm{~nm}$ ), and caffeic acid (432 nm) (Lagorio et al. 2015). Of these, all but $p$ coumaric acid and caffeic acid have absorption maxima in the UV-A range (315-400 $\mathrm{nm}$ ) (Lagorio et al. 2015) and might therefore be responsible for the fluorescence detailed herein. Ferulic acid in particular has been identified as the primary source of blue fluorescence in leaves, where it is commonly found in epidermal cell walls (Morales et al. 1996; Lichtenthaler \& Schweiger 1998; Buschmann et al. 2000; but see Chappelle et al. 1991; Morales et al. 2005). In addition, blue fluorescence from chlorophyll catabolites is commonly associated with leaf senescence (Kräutler et al. 2010; Jockusch et al. 2014) and banana ripening (Moser et al. 2008, 2009), and blue-fluorescing trichomes have been reported from a range of plant species (e.g. Lam et al. 1980; Lang \& Schindler 1994). Further work is needed to determine the source of blue fluorescence in Heliamphora and how it relates to similar optical phenomena in other plants.

Hartmeyer et al. (2013) proposed the intensely blue-fluorescent alkaloid coniine as the source of UVinduced fluorescence in the nectar of Sarracenia (from which it was first isolated by Mody et al. 1976) and possibly also Nepenthes (from which it has yet to be reported). Coniine has been variously proposed as an insect paralysing agent or an insect attractant (Mody et al. 1976; Hotti et al. 2017). Its presence in Darlingtonia is uncertain (Hotti et al. 2017); its possible occurrence in Heliamphora warrants investigation. 


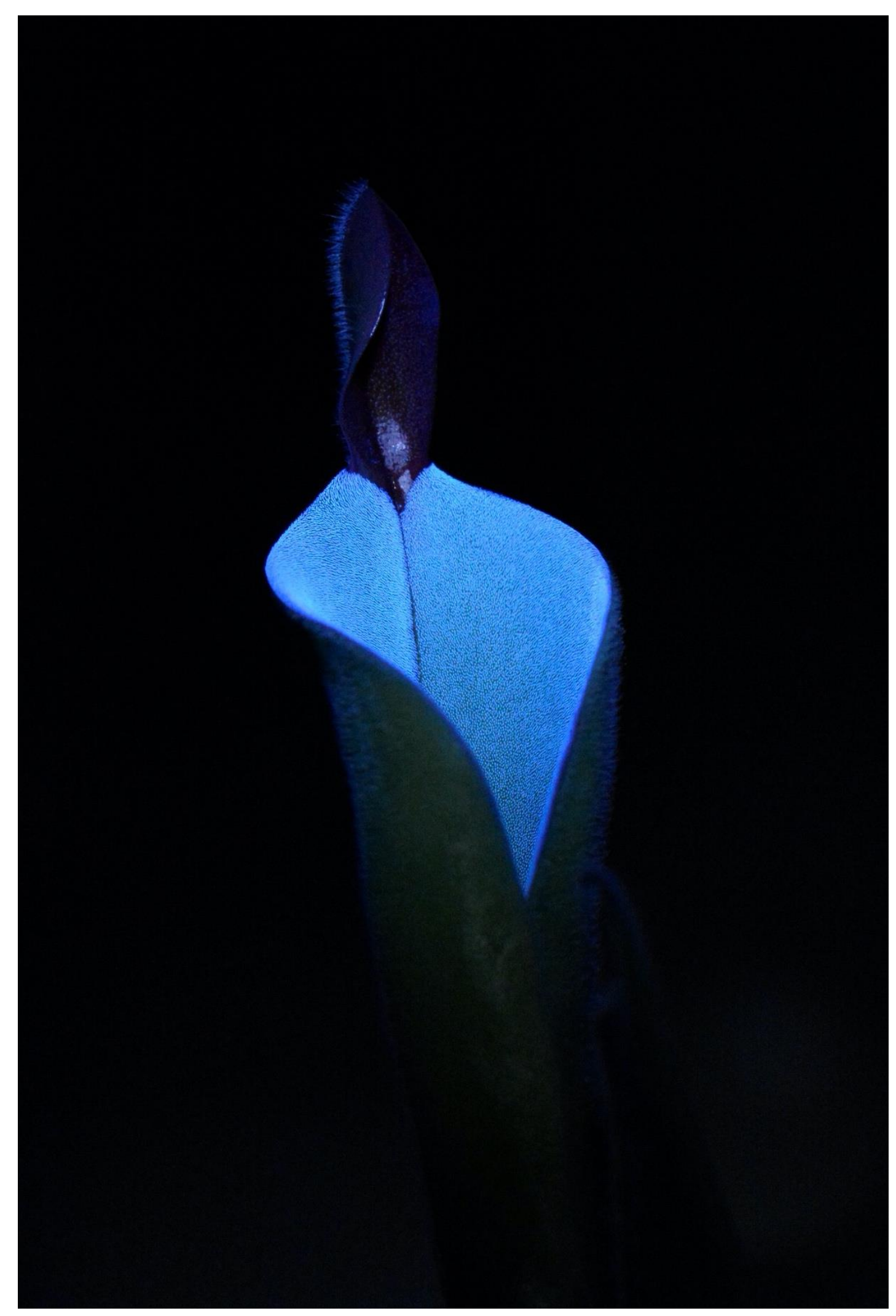

Figure 18: A recently opened inflorescence-borne pitcher of a cultivated Heliamphora parva, viewed under a UV torch. 


\section{Quenching of fluorescence in Heliamphora}

The observed loss of blue fluorescence may be attributable to chemical changes resulting from photobleaching (i.e. true quenching). Alternatively, it might be due to surface contamination (i.e. apparent quenching; see Lakowicz 1983). While organic surface contaminants were commonly observed on older pitchers in the wild (including yellow-fluorescing substances; Fig. 3D), the rapid onset and uniform nature of fluorescence loss points to a fundamental change in the chemistry of the trichomes, whether exogenous (environmental) or endogenous (developmental or otherwise physiological). Perhaps also worth considering is the so-called inner-filter effect, whereby increasing concentrations of a fluorophore can lead to self-quenching as absorption and emission spectra increasingly overlap (see Mori et al. 2018).

\section{Avenues for future research}

Fluorescence as a biologically relevant phenomenon has been largely overlooked, especially in terrestrial environments. To the author's knowledge, this paper constitutes the first published demonstration of fluorescence in Heliamphora or indeed any component of the specialised tepui flora. Further studies should be undertaken to confirm the chemical source of the blue fluorescence, characterise the timing and mechanism by which it is quenched, determine its excitation and emission spectra, and quantify the contribution of fluoresced light to total emerging blue light under various irradiance scenarios. The latter could then be related to known or inferred spectral sensitivities of ecologically relevant species (viz. prey and inquilines) to establish whether a biosignalling role is plausible. Ultimately, behavioural studies involving the putative target species would be needed to confirm fluorescent biosignalling. Potential nonecological functionality, such as in photoprotection or photosynthesis enhancement, should also be investigated.

Acknowledgements: I would like to thank Raya Al-Shawi and Paul Simons for their tireless encouragement, countless hours of fruitful discussions, and help with fluorescence microscopy. Charles Brewer-Carías, Antonio Hitcher, Stewart McPherson, Emilio Pérez, James Rosindell and Jeff Shea are thanked for their company and assistance both during and after the Venezuela trip. José Ochoa, Lorenzo Prendini and Fernando Rojas-Runjaic are thanked for sharing their expertise on tepui scorpions.

\section{References}

Adlassnig, W., Peroutka, M., and Lendl, T. 2011. Traps of carnivorous pitcher plants as a habitat: composition of the fluid, biodiversity and mutualistic activities. Annals of Botany 107(2): 181-194. https://doi.org/10.1093/aob/mcq238

Aksoy, V., and Camlitepe, Y. 2018. Spectral sensitivities of ants - a review. Animal Biology 68(1): 55-73. https://doi.org/10.1163/15707563-17000119

Allan, S.A., Day, J.F., and Edman, J.D. 1987. Visual ecology of biting flies. Annual Review of Entomology 32: 297-314. https://doi.org/10.1146/annurev.en.32.010187.001501

Andrews, K., Reed, S.M., and Masta, S.E. 2007. Spiders fluoresce variably across many taxa. Biology Letters 3(3): 265-267. https://doi.org/10.1098/rsbl.2007.0016

Arnold, K.E., Owens, I.P.F., and Marshall, N.J. 2002. Fluorescent signaling in parrots. Science 295(5552): 92. https://doi.org/10.1126/science.295.5552.92

Barrera, R., Fish, D., and Machado-Allison, C.E. 1989. Ecological patterns of aquatic insect communities in two Heliamphora pitcher-plant species of the Venezuelan highlands. Ecotropicos 2(1): 31-44.

Bauer, U., and Federle, W. 2009. The insect-trapping rim of Nepenthes pitchers: surface structure and function. Plant Signaling \& Behavior 4(11): 1019-1023. https://doi.org/10.4161/psb.4.11.9664

Bauer, U., Scharmann, M., Skepper, J., and Federle, W. 2013. 'Insect aquaplaning' on a superhydrophilic hairy surface: how Heliamphora nutans Benth. pitcher plants capture prey. Proceedings of the Royal Society B 280(1753): 20122569. https://doi.org/10.1098/rspb.2012.2569

Bazile, V. 2013. Re: CP's use UV light to catch prey. CPUK Forum, 26 February 2013. https://www.cpukforum.com/forum/index.php?/topic/48605-cps-use-uv-light-to-catchprey/\&tab=comments\#comment-330955 
Bergland, A.O., Agotsch, M., Mathias, D., Bradshaw, W.E., and Holzapfel, C.M. 2005. Factors influencing the seasonal life history of the pitcher-plant mosquito, Wyeomyia smithii. Ecological Entomology 30(2): 129-137. https://doi.org/10.1111/j.0307-6946.2005.00687.x

Bielmeier, C.M. 2009. Fluorescence in the garden. Glimpse 2(3): 10-13. https://issuu.com/glimpse journal/docs/vol2.3 color

Bloudoff-Indelicato, M. 2013. Carnivorous plants glow to attract prey. National Geographic Society Newsroom, 25 February 2013. https://blog.nationalgeographic.org/2013/02/25/carnivorous-plantsglow-to-attract-prey/

Blum, A.G. 2019. UV induced visible fluorescence. Ultraviolet Photography, 21 December 2019. http://www.ultravioletphotography.com/content/index.php/topic/1456-sticky-uv-induced-visiblefluorescence/

Bohn, H.F., and Federle, W. 2004. Insect aquaplaning: Nepenthes pitcher plants capture prey with the peristome, a fully wettable water-lubricated anisotropic surface. PNAS 101(39): 14138-14143. https://doi.org/10.1073/pnas.0405885101

Bradshaw, W.E. 1983. Interaction between the mosquito Wyeomyia smithii, the midge Metriocnemus knabi, and their carnivorous host Sarracenia purpurea. In: Frank, J.H., and Lounibos, L.P. (eds.) Phytotelmata: Terrestrial Plants as Hosts for Aquatic Insect Communities. Plexus Publishing, Medford. pp. 161-189.

Brandt, E.E., and Masta, S.E. 2017. Females are the brighter sex: differences in external fluorescence across sexes and life stages of a crab spider. PLoS ONE 12(5): e0175667. https://doi.org/10.1371/journal.pone.0175667

Brecko, J., Mathys, A., Dekoninck, W., De Ceukelaire, M., VandenSpiegel, D., and Semal, P. 2016. Revealing invisible beauty, ultra detailed: the influence of low cost UV exposure on natural history $\begin{array}{lllll}\text { specimens in 2D+ digitization. PLoS ONE 11(8): e0161572. } & \text { en }\end{array}$ https://doi.org/10.1371/journal.pone.0161572

Brewer-Carías, C. 1972. Observaciones sobre el nicho ecológico de Heliamphora: planta carnívora del Cerro de la Neblina. Natura no. 48-49: 4-7.

Brewer-Carías, C. 1973. Plantas carnívoras del Cerro de la Neblina. Estudio y fotografía sobre tres mecanismos de trampas. Defensa de la Naturaleza 2(6): 17-26.

Briscoe, A.D., and Chittka, L. 2001. The evolution of color vision in insects. Annual Review of Entomology 46: 471-510. https://doi.org/10.1146/annurev.ento.46.1.471

Buschmann, C., Langsdorf, G., and Lichtenthaler, H.K. 2000. Imaging of the blue, green, and red fluorescence emission of plants: an overview. Photosynthetica 38(4): 483-491. https://doi.org/10.1023/A:1012440903014

Carow, T. 2005. Heliamphora sarracenioides, Carow, Wistuba, Harbarth: eine neue Heliamphora Art aus Venezuela. Das Taublatt no. 52: 8-11.

Carow, T., Wistuba, A., and Harbarth, P. 2005. Heliamphora sarracenioides, a new species of Heliamphora (Sarraceniaceae) from Venezuela. Carnivorous Plant Newsletter 34(1): 4-6. https://legacy.carnivorousplants.org/cpn/Species/v34n1p4_6.html

Černohorský, Z. 1950. Fluorescence of lichens in ultra-violet light. Genus Parmelia Ach. Studia Botanica Čechoslovaca 11: 98-100. https://books.google.com/books?id=S9xEAAAAYAAJ

Chappelle, E.W., McMurtrey III, J.E., and Kim, M.S. 1991. Identification of the pigment responsible for the blue fluorescence band in the laser induced fluorescence (LIF) spectra of green plants, and the potential use of this band in remotely estimating rates of photosynthesis. Remote Sensing of Environment 36(3): 213-218. https://doi.org/10.1016/0034-4257(91)90058-E

Christmann, J. 2016. Re: UV fluorescence in CPs. Terraforums.com, 10 November 2016. https://www.terraforums.com/forums/general-discussions/141117-uv-fluorescencecps.html\#post1202979

Clarke, C.M., Moran, J.A., and Lee, C.C. 2011. Nepenthes baramensis (Nepenthaceae) - a new species from north-western Borneo. Blumea 56(3): 229-233. https://doi.org/10.3767/000651911X607121

Cross, A., Kalfas, N., Nunn, R., and Conran, J. 2019. Ultraviolet advertisement. In: Cephalotus: the Albany Pitcher Plant. Redfern Natural History Productions, Poole. pp. 78-80. 
Davies, K.L., Stpiczyńska, M., and Gregg, A. 2005. Nectar-secreting floral stomata in Maxillaria anceps Ames \& C. Schweinf. (Orchidaceae). Annals of Botany 96(2): 217-227. https://doi.org/10.1093/aob/mci182

Dyer, A.G., and Neumeyer, C. 2005. Simultaneous and successive colour discrimination in the honeybee (Apis mellifera). Journal of Comparative Physiology A 191(6): 547-557. https://doi.org/10.1007/s00359-005-0622-z

Fish, D., and Hall, D.W. 1978. Succession and stratification of aquatic insects inhabiting the leaves of the insectivorous pitcher plant, Sarracenia purpurea. The American Midland Naturalist 99(1): 172-183. https://doi.org/10.2307/2424941

Fleischmann, A., and McPherson, S.R. 2009. Some ecological notes on Heliamphora (Sarraceniaceae) from Ptari-tepui. Carniflora Australis 7(2): 19-31.

Frank, J.H. 1986. Bromeliads as ovipositional sites for Wyeomyia mosquitoes: form and color influence behavior. The Florida Entomologist 69(4): 728-742. https://doi.org/10.2307/3495221

Fukui, H., Hirai, N., Mori, S., Goto, K., Toyoda, J., and Tsukioka, J. 2017. Floral fluorescence database. The Garden of Medicinal Plans, Kyoto Pharmaceutical University. http://labo.kyotophu.ac.jp/mpgkpu/ffd.html

Gaffin, D.D., Bumm, L.A., Taylor, M.S., Popokina, N.V., and Mann, S. 2012. Scorpion fluorescence and reaction to light. Animal Behaviour 83(2): 429-436. https://doi.org/10.1016/j.anbehav.2011.11.014

Gandía-Herrero, F., García-Carmona, F., and Escribano, J. 2005a. Floral fluorescence effect. Nature 437(7057): 334. https://doi.org/10.1038/437334a

Gandía-Herrero, F., Escribano, J., and García-Carmona, F. 2005b. Betaxanthins as pigments responsible for visible fluorescence in flowers. Planta 222(4): 586-593. https://doi.org/10.1007/s00425-005-0004-3

García-Plazaola, J.I., Fernández-Marín, B., Duke, S.O., Hernández, A., López-Arbeloa, F., and Becerril, J.M. 2015. Autofluorescence: biological functions and technical applications. Plant Science 236: 136145. https://doi.org/10.1016/j.plantsci.2015.03.010

Gaume, L., Perret, P., Gorb, E., Gorb, S., Labat, J.-J., and Rowe, N. 2004. How do plant waxes cause flies to slide? Experimental tests of wax-based trapping mechanisms in three pitfall carnivorous plants. Arthropod Structure and Development 33(1): 103-111. https://doi.org/10.1016/j.asd.2003.11.005

Glossner, F. 1992. Ultraviolet patterns in the traps and flowers of some carnivorous plants. Botanische Jahrbücher für Systematik Pflanzengeschichte und Pflanzengeographie 113(4): 577-587.

Gonzalez, J.M., Jaffe, K., and Michelangeli, F. 1991. Competition for prey between the carnivorous Bromeliaceae Brocchinia reducta and Sarraceneacea Heliamphora nutans. Biotropica 23(4b): 602-604. https://doi.org/10.2307/2388398

Gruber, D.F., Loew, E.R., Deheyn, D.D., Akkaynak, D., Gaffney, J.P., Smith, W.L., Davis, M.P., Stern, J.H., Pieribone, V.A., and Sparks, J.S. 2016. Biofluorescence in catsharks (Scyliorhinidae): fundamental description and relevance for elasmobranch visual ecology. Scientific Reports 6: 24751. https://doi.org/10.1038/srep24751

Guerrero-Rubio, M.A., Escribano, J., García-Carmona, F., and Gandía-Herrero, F. 2020. Light emission in betalains: from fluorescent flowers to biotechnological applications. Trends in Plant Science 25(2): 159175. https://doi.org/10.1016/j.tplants.2019.11.001

Haddock, S.H.D., and Dunn, C.W. 2015. Fluorescent proteins function as a prey attractant: experimental evidence from the hydromedusa Olindias formosus and other marine organisms. Biology Open 4: 10941104. https://doi.org/10.1242/bio.012138

Haddock, S.H.D., Dunn, C.W., Pugh, P.R., and Schnitzler, C.E. 2005. Bioluminescent and red-fluorescent lures in a deep-sea siphonophore. Science 309(5732): 263. https://doi.org/10.1126/science.1110441

Haridas, V. 2014. Glow to survive. C-DIT Production. https://www.youtube.com/watch?v=XcEJKkBTIK0

Hartmeyer, S.R.H., Bayerl, R., and Hartmeyer, I. 2013. Leuchtende Karnivoren: die Lumineszenz der Schierlingsbecher. Das Taublatt no. 33-44. http://www.hartmeyer.de/ArtikelundBerichte/artlumineszenz Taublatt2013.html

Holovachov, O. 2015a. Ultraviolet-induced visible fluorescence photography. Holovachov.com, 4 February 2015. http://www.holovachov.com/fluorescence 
Holovachov, O. 2015b. Unseen beauty of flowers - hidden signals or spectacular by-product? Green Letters 19(3): 329-331. https://doi.org/10.1080/14688417.2015.1078121

Hoque, E., and Remus, G. 1999. Natural UV-screening mechanisms of Norway spruce (Picea abies [L.] Karst.) needles. Photochemistry and Photobiology 69(2): 177-192. https://doi.org/10.1111/j.17511097.1999.tb03272.X

Horner, J.D., Płachno, B.J., Bauer, U., and Di Giusto, B. 2018. Attraction of prey. In: Ellison, A.M., and Adamec, L. (eds.) Carnivorous Plants: Physiology, Ecology, and Evolution. Oxford University Press, Oxford. pp. 157-166. http://doi.org/10.1093/oso/9780198779841.003.0012

Hotti, H., Gopalacharyulu, P., Seppänen-Laakso, T., and Rischer, H. 2017. Metabolite profiling of the carnivorous pitcher plants Darlingtonia and Sarracenia. PLoS ONE 12(2): e0171078. https://doi.org/10.1371/journal.pone.0171078

Ingles-Le Nobel, J.J. 2018. Lighting for UV macro. Extreme Macro, 30 September 2018. http://extrememacro.co.uk/uv-macro-lighting/

Iriel, A., and Lagorio, M.G. 2010a. Implications of reflectance and fluorescence of Rhododendron indicum flowers in biosignaling. Photochemical \& Photobiological Sciences 9(3): 342-348. https://doi.org/10.1039/B9PP00104B

Iriel, A., and Lagorio, M.G. 2010b. Is the flower fluorescence relevant in biocommunication? Naturwissenschaften 97(10): 915-924. https://doi.org/10.1007/s00114-010-0709-4

Istock, C.A., Tanner, K., and Zimmer, H. 1983. Habitat selection by the pitcher-plant mosquito, Wyeomyia smithii: behavioral and genetic aspects. In: Frank, J.H., and Lounibos, L.P. (eds.) Phytotelmata: Terrestrial Plants as Hosts for Aquatic Insect Communities. Plexus Publishing, Medford. pp. 191-204.

Jaffe, K., Michelangeli, F., Gonzalez, J.M., Miras, B., and Ruiz, M.C. 1992. Carnivory in pitcher plants of the genus Heliamphora (Sarraceniaceae). New Phytologist 122(4): 733-744. https://doi.org/10.1111/j.1469-8137.1992.tb00102.x

Jaffe, K., Blum, M.S., Fales, H.M., Mason, R.T., and Cabrera, A. 1995. On insect attractants from pitcher plants of the genus Heliamphora (Sarraceniaceae). Journal of Chemical Ecology 21(3): 379-384. https://doi.org/10.1007/BF02036725

Jansen, M.A.K. 2017. Carnivorous plants and UV-radiation: a captivating story? UV4Plants Bulletin [2017](1): 11-16. https://doi.org/10.19232/uv4pb.2017.1.12

Jockusch, S., Turro, N.J., Banala, S., and Kräutler, B. 2014. Photochemical studies of a fluorescent chlorophyll catabolite - source of bright blue fluorescence in plant tissue and efficient sensitizer of singlet oxygen. Photochemical \& Photobiological Sciences 13(2): 407-411. https://doi.org/10.1039/C3PP50392E

Joel, D.M. 1983. UV patterns of carnivorous plants. Israel Journal of Botany 32(1): 45. [abstract] https://www.tandfonline.com/doi/pdf/10.1080/0021213X.1983.10676963

Joel, D.M. 1988. Mimicry and mutualism in carnivorous pitcher plants (Sarraceniaceae, Nepenthaceae, Cephalotaceae, Bromeliaceae). Biological Journal of the Linnean Society 35(2): 185-197. https://doi.org/10.1111/j.1095-8312.1988.tb00465.x

Joel, D.M., Juniper, B.E., and Dafni, A. 1985. Ultraviolet patterns in the traps of carnivorous plants. New Phytologist 101(4): 585-593. https://doi.org/10.1111/j.1469-8137.1985.tb02864.x

Johnsen, S. 2012. Fluorescence. In: The Optics of Life: A Biologist's Guide to Light in Nature. Princeton University Press, Princeton. pp. 181-202.

Johnsen, S., Kelber, A., Warrant, E., Sweeney, A.M., Widder, E.A., Lee, Jr., R.L., and Hernández-Andrés, J. 2006. Crepuscular and nocturnal illumination and its effects on color perception by the nocturnal hawkmoth Deilephila elpenor. Journal of Experimental Biology 209(5): 789-800. https://doi.org/10.1242/jeb.02053

Johnson, G.A., Mantha, S.V., and Day, T.A. 2000. A spectrofluorometric survey of UV-induced blue-green fluorescence in foliage of 35 species. Journal of Plant Physiology 156(2): 242-252. https://doi.org/10.1016/S0176-1617(00)80313-2

Juniper, B.E., Robins, R.J., and Joel, D.M. 1989. The Carnivorous Plants. Academic Press, London. 
Kevan, P.G. 1976. Fluorescent nectar. Science 194(4262): 341-342. https://doi.org/10.1126/science.194.4262.341

Kevan, P.G., Chittka, L., and Dyer, A.G. 2001. Limits to the salience of ultraviolet: lessons from colour vision in bees and birds. Journal of Experimental Biology 204(14): 2571-2580. https://jeb.biologists.org/content/204/14/2571

Kohler, A.M., Olson, E.R., Martin, J.G., and Anich, P.S. 2019. Ultraviolet fluorescence discovered in New World flying squirrels (Glaucomys). Journal of Mammalogy 100(1): 21-30. https://doi.org/10.1093/jmammal/gyy177

Kräutler, B., Banala, S., Moser, S., Vergeiner, C., Müller, T., Lütz, C., and Holzinger, A. 2010. A novel blue fluorescent chlorophyll catabolite accumulates in senescent leaves of the peace lily and indicates a split path of chlorophyll breakdown. FEBS Letters 584(19): 4215-4221. https://doi.org/10.1016/j.febslet.2010.09.011

Kurup, R., Johnson, A.J., Sankar, S., Hussain, A.A., Sathish Kumar, C., and Sabulal, B. 2013. Fluorescent prey traps in carnivorous plants. Plant Biology 15(3): 611-615. https://doi.org/10.1111/j.14388677.2012.00709.x

Lagorio, M.G., Cordon, G.B., and Iriel, A. 2015. Reviewing the relevance of fluorescence in biological systems. Photochemical \& Photobiological Sciences 14(9): 1538-1559. https://doi.org/10.1039/C5PP00122F

Lakowicz J.R. 1983. Quenching of fluorescence. In: Principles of Fluorescence Spectroscopy. Springer, Boston. pp. 257-301. https://doi.org/10.1007/978-1-4615-7658-7_9

Lam, T.H., Ho, Y.B., and Chen, S. 1980. Observations on ultraviolet-fluorescent trichomes on the tepals of Narcissus flowers. Plant Science Letters 18(2): 115-120. https://doi.org/10.1016/0304-4211(80)90039$\underline{5}$

Lamb, J.Y., and Davis, M.P. 2020. Salamanders and other amphibians are aglow with biofluorescence. Scientific Reports 10: 2821. https://doi.org/10.1038/s41598-020-59528-9

Lang, M., and Schindler, C. 1994. The effect of leaf-hairs on blue and red fluorescence emission and on zeaxanthin cycle performance of Senecio medley L. Journal of Plant Physiology 144(6): 680-685. https://doi.org/10.1016/S0176-1617(11)80660-7

Lang, M., Siffel, P., Braunová, Z., and Lichtenthaler, H.K. 1992. Investigations of the blue-green fluorescence emission of plant leaves. Botanica Acta 105(6): 435-440. https://doi.org/10.1111/j.14388677.1992.tb00325.x

Lichtenthaler, H.K., and Schweiger, J. 1998. Cell wall bound ferulic acid, the major substance of the bluegreen fluorescence emission of plants. Journal of Plant Physiology 152(2-3): 272-282. https://doi.org/10.1016/S0176-1617(98)80142-9

Lim, M.L.M., Land, M.F., and Li, D. 2007. Sex-specific UV and fluorescence signals in jumping spiders. Science 315(5811): 481. https://doi.org/10.1126/science.1134254

Liu, S., and Smith, S.D. 2020. Phylogeny and biogeography of South American marsh pitcher plant genus Heliamphora (Sarraceniaceae) endemic to the Guiana Highlands. bioRxiv preprint, 30 April 2020. https://doi.org/10.1101/2020.04.29.068395

Lloyd, F.E. 1924. The fluorescent colors of plants. Science 59(1524): 241-248. https://doi.org/10.1126/science.59.1524.241

Lloyd, F.E. 1942. The Carnivorous Plants. Chronica Botanica Company, Waltham.

Macel, M.-L., Ristoratore, F., Locascio, A., Spagnuolo, A., Sordino, P., and D’Aniello, S. 2020. Sea as a color palette: the ecology and evolution of fluorescence. Zoological Letters 6: 9. https://doi.org/10.1186/s40851-020-00161-9

Marshall, J., and Johnsen, S. 2017. Fluorescence as a means of colour signal enhancement. Philosophical Transactions of the Royal Society B: Biological Sciences 372(1724): 20160335. https://doi.org/10.1098/rstb.2016.0335

Mazel, C.H. 2017. Method for determining the contribution of fluorescence to an optical signature, with implications for postulating a visual function. Frontiers in Marine Science 4: 266. https://doi.org/10.3389/fmars.2017.00266 
Mazel, C.H., Cronin, T.W., Caldwell, R.L., and Marshall, N.J. 2004. Fluorescent enhancement of signaling in a mantis shrimp. Science 303(5654): 51. https://doi.org/10.1126/science.1089803

McPherson, S.R. 2006. Pitcher Plants of the Americas. The McDonald \& Woodward Publishing Company, Blacksburg.

McPherson, S.R., Wistuba, A., Fleischmann, A., and Nerz, J. 2011. Sarraceniaceae of South America. Redfern Natural History Productions, Poole.

Michiels, N.K., Anthes, N., Hart, N.S., Herler, J., Meixner, A.J., Schleifenbaum, F., Schulte, G., Siebeck, U.E., Sprenger, D., and Wucherer, M.F. 2008. Red fluorescence in reef fish: a novel signalling mechanism? BMC Ecology 8: 16. https://doi.org/10.1186/1472-6785-8-16

Miller, T.E., and terHorst, C.P. 2012. Testing successional hypotheses of stability, heterogeneity, and diversity in pitcher-plant inquiline communities. Oecologia 170(1): 243-251. https://doi.org/10.1007/s00442-012-2292-1

Mody, N.V., Henson, R., Hedin, P.A., Kokpol, U., and Miles, D.H. 1976. Isolation of the insect paralyzing agent coniine from Sarracenia flava. Experientia 32(7): 829-830. https://doi.org/10.1007/BF02003710

Mogi, M., and Mokry, J. 1980. Distribution of Wyeomyia smithii (Diptera, Culicidae) eggs in pitcher plants in Newfoundland, Canada. Tropical Medicine 22: 1-12.

Morales, F., Cerovic, Z.G., and Moya, I. 1996. Time-resolved blue-green fluorescence of sugar beet (Beta vulgaris L.) leaves. Spectroscopic evidence for the presence of ferulic acid as the main fluorophore of the epidermis. Biochimica et Biophysica Acta - Bioenergetics 1273(3): 251-262. https://doi.org/10.1016/0005-2728(95)00153-0

Morales, F., Cartelat, A., Álvarez-Fernández, A., Moya, I., and Cerovic, Z.G. 2005. Time-resolved spectral studies of blue-green fluorescence of artichoke (Cynara cardunculus L. var. scolymus) leaves: identification of chlorogenic acid as one of the major fluorophores and age-mediated changes. Journal of Agricultural and Food Chemistry 53(25): 9668-9678. https://doi.org/10.1021/jf051842q

Moran, J.A. 1991. The role and mechanism of Nepenthes rafflesiana pitchers as insect traps in Brunei. Unpublished Ph.D. thesis, University of Aberdeen, Aberdeen. http://digitool.abdn.ac.uk/R?func=searchadvanced-go\&find_code1=WSN\&request1=AAIU547158

Moran J.A. 1996. Pitcher dimorphism, prey composition and the mechanisms of prey attraction in the pitcher plant Nepenthes rafflesiana in Borneo. Journal of Ecology 84(4): 515-525. https://doi.org/10.2307/2261474

Moran, J.A., Booth, W.E., and Charles, J.K. 1999. Aspects of pitcher morphology and spectral characteristics of six Bornean Nepenthes pitcher plant species: implications for prey capture. Annals of Botany 83(5): 521-528. https://doi.org/10.1006/anbo.1999.0857

Moran, J.A., Clarke, C., Greenwod, M., and Chin, L. 2012. Tuning of color contrast signals to visual sensitivity maxima of tree shrews by three Bornean highland Nepenthes species. Plant Signalling and Behavior 7(10): 1267-1270. https://doi.org/10.4161/psb.21661

Mori, S., and Hirai, N. 2019. [Ecological function of fluorescent substances contained in pollen-does fluorescence of pollen attract honeybees?] Japanese Journal of Pesticide Science 44(2): 244-245. https://doi.org/10.1584/jpestics.W19-30

Mori, S., Fukui, H., Oishi, M., Sakuma, M., Kawakami, M., Tsukioka, J., Goto, K., and Hirai, N. 2018. Biocommunication between plants and pollinating insects through fluorescence of pollen and anthers. Journal of Chemical Ecology 44(6): 591-600. https://doi.org/10.1007/s10886-018-0958-9

Moser, S., Müller, T., Ebert, M.-O., Jockusch, S., Turro, N.J., and Kräutler, B. 2008. Blue luminescence of ripening bananas. Angewandte Chemie International Edition 47(46): 8954-8957. https://doi.org/10.1002/anie.200803189

Moser, S., Müller, T., Holzinger, A., Lütz, C., Jockusch, S., Turro, N.J., and Kräutler, B. 2009. Fluorescent chlorophyll catabolites in bananas light up blue halos of cell death. PNAS 106(37): 15538-15543. https://doi.org/10.1073/pnas.0908060106

Nastase, A.J., de la Rosa, C., and Newell, S.J. 1995. Abundance of pitcher-plant mosquitoes, Wyeomyia smithii (Coq.) (Diptera: Culicidae) and midges, Metriocnemus knabi Coq. (Diptera: Chironomidae), in 
relation to pitcher characteristics of Sarracenia purpurea L. The American Midland Naturalist 133(1): 44-51. https://doi.org/10.2307/2426346

Ochoa, J.A., and Rojas-Runjaic, F.J.M. 2019. Scorpions. In: Rull, V., Vegas-Vilarrúbia, T., Huber, O., and Señaris, C. (eds.) Biodiversity of Pantepui: The Pristine "Lost World" of the Neotropical Guiana Highlands. Academic Press, London. pp. 223-246.

Płachno, B.J., Świątek, P., and Wistuba, A. 2007. The giant extra-floral nectaries of carnivorous Heliamphora folliculata: architecture and ultrastructure. Acta Biologica Cracoviensia: Series Botanica 49(2): 91-104.

Poppinga, S., Koch, K., Bohn, H.F., and Barthlott, W. 2010. Comparative and functional morphology of hierarchically structured anti-adhesive surfaces in carnivorous plants and kettle trap flowers. Functional Plant Biology 37(10): 952-961. https://doi.org/10.1071/FP10061

Prötzel, D., Heß, M., Scherz, M.D., Schwager, M., van't Padje, P., and Glaw, F. 2018. Widespread bonebased fluorescence in chameleons. Scientific Reports 8: 698. https://doi.org/10.1038/s41598-01719070-7

Rørslett, B. 2006. Flowers in ultraviolet arranged by plant family. Naturfotograf.com, 24 October 2006. http://www.naturfotograf.com/UV_flowers_list.html

Roshchina, V.V. 2008. Fluorescing World of Plant Secreting Cells. Science Publishers, Enfield. https://books.google.com/books?id=OWO1DwAAQBAJ\&vq

Rost, F.W.D. 1995. Autofluorescence in plants, fungi and bacteria. In: Fluorescence Microscopy, vol. 2. Cambridge University Press, Cambridge. pp. 16-39. https://books.google.com/books?id=-eJsstG ClcC

Sabulal, B., Johnson, A.J., Govindan, B., Lukose, S., Gopakumar, B., and Koshy, K.C. 2013. UV induced visual cues in grasses. Scientific Reports 3: 2738. https://doi.org/10.1038/srep02738

Salih, A., Larkum, A., Cox, G., Kühl, M., and Hoegh-Guldberg, O. 2000. Fluorescent pigments in corals are photoprotective. Nature 408(6814): 850-853. https://doi.org/10.1038/35048564

Schlichter, D., Meier, U., and Fricke, H.W. 1994. Improvement of photosynthesis in zooxanthellate corals by autofluorescent chromatophores. Oecologia 99(1-2): 124-131. https://doi.org/10.1007/BF00317092

Song, B.-M., and Lee, C.-H. 2018. Toward a mechanistic understanding of color vision in insects. Frontiers in Neural Circuits 12: 16. https://doi.org/10.3389/fncir.2018.00016

Sparks, J.S., Schelly, R.C., Smith, W.L., Davis, M.P., Tchernov, D., Pieribone, V.A., and Gruber, D.F. 2014. The covert world of fish biofluorescence: a phylogenetically widespread and phenotypically variable phenomenon. PLoS ONE 9(1): e83259. https://doi.org/10.1371/journal.pone.0083259

Stromberg, J. 2013. These carnivorous plants glow under ultraviolet light to attract prey. Smithsonian Magazine, 11 December 2013. https://www.smithsonianmag.com/science-nature/these-carnivorousplants-glow-under-ultraviolet-light-to-attract-prey-180948058/

Studnička, M. 2003. Observations on life strategies of Genlisea, Heliamphora, and Utricularia in natural habitats. $\quad$ Carnivorous Plant Newsletter https://cpn.carnivorousplants.org/articles/CPNv32n2p57 61.pdf

Taboada, C., Brunetti, A.E., Pedron, F.N., Neto, F.C., Estrin, D.A., Bari, S.E., Chemes, L.B., Lopes, N.P., Lagorio, M.G., and Faivovich, J. 2017a. Naturally occurring fluorescence in frogs. PNAS 114(14): 3672-3677. https://doi.org/10.1073/pnas.1701053114

Taboada, C., Brunetti, A.E., Alexandre, C., Lagorio, M.G., and Faivovich, F. 2017b. Fluorescent frogs: a herpetological perspective. South American Journal of Herpetology 12(1): 1-13. https://doi.org/10.2994/SAJH-D-17-00029.1

Thorp, R.W., Briggs, D.L., Estes, J.R., and Erickson, E.H. 1975. Nectar fluorescence under ultraviolet irradiation. Science 189(4201): 476-478. https://doi.org/10.1126/science.189.4201.476

van der Kooi, C.J., Dyer, A.G., Kevan, P.G., and Lunau, K. 2019. Functional significance of the optical properties of flowers for visual signalling. Annals of Botany 123(2): 263-276. https://doi.org/10.1093/aob/mcy119

Vukusic, P., and Hooper, I. 2005. Directionally controlled fluorescence emission in butterflies. Science 310(5751): 1151. https://doi.org/10.1126/science.1116612 
Warwicker, M. 2013. Carnivorous plant species glow blue to lure prey. BBC Nature News, 19 February 2013. https://web.archive.org/web/20130220054203/https://www.bbc.co.uk/nature/21459520

Williams, R.E. 1962. Effect of coloring oviposition media with regard to the mosquito Aedes triseriatus (Say). The Journal of Parasitology 48(6): 919-925. https://doi.org/10.2307/3275123

Williams, S.E., and Hartmeyer, S.R.H. 2017. Prey capture by Dionaea muscipula: a review of scientific literature with supplementary original research. Carnivorous Plant Newsletter 46(2): 44-61. https://cpn.carnivorousplants.org/articles/CPNv46n2p44_61.pdf

Zavortink, TJ. 1985. Zinzala, a new subgenus of Wyeomyia with two new species from pitcher-plants in Venezuela (Diptera, Culicidae, Sabethini). The Wasmann Journal of Biology 43(1-2): 46-59.

Golos, Michal R. 2020. First observations of UV-induced fluorescence in Heliamphora (Sarraceniaceae) and other tepui flora. Carniv. PI. Newslett. 49(4): e1-31.

https://cpn.carnivorousplants.org/articles/CPNv49n4pe1 31.pdf

Published online December 1, 2020. (C) 2020 International Carnivorous Plant Society. All rights reserved.

Carnivorous Plant Newsletter is published quarterly in March, June, September, and December by the International Carnivorous Plant Society, Inc., 2121 N. California Blvd., Suite 290, Walnut Creek, CA 94596, USA. 